\title{
Psychological Capital in Educational Context: Lifelong Learning and Beyond Hope
}

\author{
Mei-Ling, $\operatorname{Lin}^{1}$ \\ ${ }^{1}$ Department of Social Science, National Open University, Taiwan R.O.C. \\ Correspondence: Mei-Ling, Lin, Department of Social Science, National Open University, Taiwan R.O.C.
}

Received: February 22, 2021

Accepted: March 18, 2021

Available online: March 24, 2021

doi:10.11114/ijsss.v9i3.5199

URL: https://doi.org/10.11114/ijsss.v9i3.5199

\begin{abstract}
The world of work is constantly changing whereby innovation and challenges requires oneself to be competitive. Although, human capital and social capital are vital to the success, psychological capital (PsyCap) has been proposed as a new complementary concept that remains in success. Research proves that hope is a good predictor of subjective well-being. Promoting academic PsyCap helps achieve academic success. The author attempts to draw parallels to consider the construct of PsyCap that can predict educational success, substantiates the assumptions in light of results of survey "Psychological Perspectives on Perceived Hope", and highlights the significant relationships between hope, PsyCap and other relevant variables that impact educational and future life success. These dynamics of lifelong learning, hope, and psychological capital needs further empirical clarification. The purpose of this paper is to present the local results, especially the assessment of the social and psychological aspects of hope in relation to lifelong learning. Accordingly, the paper has three aims: Firstly, what is the role of the demographic structure of the samples in enabling social change (optimism and enthusiasm, happy life years, self-efficacy) and hope of life (well-being, basic human needs, life satisfaction)? Secondly, what are the predictability of social change and hope of life? Thirdly, what are the correlation of social change and hope of life? These research questions capture broader social and psychological debates about the topics of lifelong learning, social exclusion, well-being, hope and psychological capital, and they also assist us to progress the discussions around the hope for a good life. SPSS (t-test, ANOVA, multiple regression analysis, canonical correlation analysis) is utilized to gather descriptive statistics.
\end{abstract}

Keywords: lifelong learning, social exclusion, well-being, hope, psychological capital

\section{Introduction}

\subsection{Diversity \& Social Development}

The changing economic and social conditions, and the development of the technological changes create challenges in terms of understanding people's lifestyles (Johansson \& Herz, 2019; Duttenhöfer, 2019). The World Bank recommended that social development should be based on a deep knowledge of local context (Thapa, 2019). Prosociality refers to behaviours and values related to helping and doing good to others (Krishnan, 2019). People need to know if the local communities live in good societies and enjoy good lives (Bericat, Camarero, \& Jiménez-Rodrigo, 2019). Society agenda is to encourage a diversity of service providers (Ní Shé, Burton, \& Danaher, 2018). In order to understand the differentiation of lifestyles, we need to focus on the learning processes and to look at how subjectivities are being formed (Johansson \& Herz, 2019). Research on diversities led to a number of approaches for understanding sociocultural-economic conflicts and inequalities, and enabled policy to achieve equality of opportunities (Thapa, 2019). One of the objectives of the paper is to point out the need for inculcating prosocial values in our society, so that we move towards societal development with a human face.

\subsection{Hope \& Well-Being}

Hope has been embedded in the human emotions (Krafft \& Walker, 2018a), and has been shown to act as a good predictor for some relevant variables in the mental health and academic development. People with a hopeful vision tend to think more about life experiences which are satisfactory, and strive hard to achieve their goals (Flores-Lucas, Martínez-Sinovas, \& Choubisa, 2018). Hope can be a valuable psychological resource that having a sense of meaning in life seems to be important to developing a meaningful career (Guse \& Shaw, 2018). Well-being is a multidimensional concept (Camarero, 2019a). Sociologists try to estimate the quality of life by focusing on indicators (income, education, 
career, etc.), while overlooking the personal attitudes (hope, well-being, etc.) (Ozan, Mierina, \& Koroleva, 2018). Since higher levels of well-being have been associated with positive outcomes in life domains, it is important to examine factors which could promote well-being (Guse \& Shaw, 2018). These dynamics of lifelong learning, hope, and psychological capital needs further empirical clarification.

\subsection{Human Capital \& Education}

Human capital not only generates returns in the economic sphere but is also key to strengthen the sustainable growth of a society (Herrera-Usagre, 2019). Education plays a central role in the formation of subject positions (Camarero, 2019a), especially higher education (HE) has become increasingly important in determining an individual's life course. This is particularly relevant in the local communities, Taiwan context, where higher education is viewed as the pathway to a better future. It is important to examine factors which may support well-being and university success. These factors may also play a part in obtaining employment and maintaining positive psychological functioning (Guse \& Shaw, 2018). A composite index in the social justice includes equitable education, labor market access, and social cohesion (Jiménez-Rodrigo, 2019). Education is conjured up as the panacea, but it does not appear to be bearing any great fruit. Education must change (Druyen, 2019).

\subsection{Psychological Capital \& Education}

The world of work is constantly changing whereby innovation and challenges require oneself to be competitive. Although, human capital and social capital are vital to the success, Psychological Capital (PsyCap) has been proposed as a new complementary concept in future success (Flores-Lucas, Martínez-Sinovas, \& Choubisa, 2018). Psychology has the conceptual tools for understanding this intersection between individual subjectivities and societal forces (Zittoun \& Gillespie, 2018). It is crucial to bridge the gap between the psychological and sociological approaches to the study of life course (Flores-Lucas, Martínez-Sinovas, \& Choubisa, 2018). Promoting academic PsyCap helps achieve academic success. Because there is an absence of research on perceived hope in the local community, the author attempts to draw parallels to consider the construct of PsyCap that can predict the educational success. The educators should explore the pedagogical elements that lead to healthier and happier classrooms.

\subsection{Local Community}

The local communities, Taiwan has been going through massive economic reforms and liberalizations. But Taiwan continues to face problems of poverty, socio-economic marginalization and social exclusion (Sinha, 2019). Taiwan has expressed its political commitment to promoting well-being among people, especially, has given priority to fighting poverty and social exclusion. Such policies drive in improving people's well-being, and the recognition of people's rights to having a good future life chances (Pollock, Ozan, \& Goswami, 2018), and target unemployment, education and training. The social policy has two major objectives: Firstly, to foster social inclusion; Secondly, to provide opportunities and equality for people in regard to employment and education (Backeberg \& Busse, 2018). There is an urgent need to understand the way globalization shapes job-seeking behaviour of educated youth. This author reviews the developments on ways to reduce the negative impact of social exclusion, and helps bridge the gap between different psychological approaches to the topics of hope and education.

Maintaining positive and meaningful social connections is a basic human need; social acceptance is linked to well-being (Fung, Xu, Glazier, Parsons, \& Alden, 2016). The aim of this paper is to demonstrate how the assumptions of social psychology have shaped our understanding of relationships between two things: the social and the psychological (Watts, 2017). Such a survey would inform future social innovations where there are needs to improve public service outcomes (Pollock, Ozan, Goswami, \& Fox, 2018). The author substantiates the assumptions in light of results of survey "Psychological Perspectives on Perceived Hope" and highlights the significant relationships between hope, PsyCap and other relevant variables that impact educational and future life success (Flores-Lucas, Martínez-Sinovas, \& Choubisa, 2018). The purpose of this paper is to present the local results, especially the assessment of the social and psychological aspects of hope and education.

\subsection{Recent Research}

Cummins and Lau developed a Personal Well-being Index covering the domains of standard of living, personal health, achievement in life, personal relationships, personal safety, feeling part of the community, and future security. The Tellus survey in the UK surveyed young people about their well-being under the five themes - be healthy, stay safe, enjoy and achieve, make a positive contribution and achieve economic well-being. OECD countries focus on six well-being domains: material well-being, housing and environment, education, health, risk behaviours, and quality of school life (Pollock, Ozan, \& Goswami, 2018). The Adult Hope Scale (AHS) measures hope as a cognitive-motivational construct that contains 12 items, of which four measure the pathways (cognitive) construct of hope, four measure the agency (motivational) construct, and four serve as distracters. The Perceived Hope Scale (PHS) taps into 
self-transcendent, spiritual, and religious elements of hope (Guse \& Shaw, 2018).

\subsection{Theoretical Approaches}

\subsubsection{Diversity \& Equity}

Development is defined as economic growth plus social change (Thapa, 2019). Diversity and equity are the fundamental constituents of the concept of multiculturalism (Berry, 2019). Sources of social diversities causing inequalities impact social-economic and human development causing inequalities to people (Pandey, 2019). A person's social class often represents a complex interplay of the family background and social networks; inequalities are reproduced in a variety of contexts (Day, Rickett, \& Woolhouse, 2017).

\subsubsection{Social Exclusion}

Most theorists agree that two core experiences of social exclusion are rejection and ostracism (Wesselmann et al., 2016; Eck \& Riva, 2016; O’Reilly \& Banki, 2016; Bernstein, 2016). Social exclusion means "being kept apart from others physically or emotionally" (Eck \& Riva, 2016; Riva \& Eck, 2016). The exclusive behavior perpetuates social hierarchies that restrict access to resources for disadvantaged groups (Elenbaas and Killen, 2016). Exclusion is a unique predictor of anxiety disorders (Fung, Xu, Glazier, Parsons, \& Alden, 2016) that reduces self-esteem and causes emotional pain in its victims (Bernstein, 2016). Poulsen found that women make more internal attributions for social exclusion than men do (O'Reilly \& Banki, 2016). Human beings are essentially social beings that they forge social connections with others to obtain survival advantages (Wesselmann et al., 2016). Individuals who fail to end the social exclusion may cause feelings of alienation and depression (Eck \& Riva, 2016). However, preventing social exclusion is best accomplished by using positive human resource, such as developing an inclusive environment (O'Reilly \& Banki, 2016). Thus, regulating emotions following social exclusion may represent one effective way to help maintain psychological well-being (Riva, 2016).

\subsubsection{Well-Being}

The field of well-being studies is multifaceted (Krafft \& Walker, 2018a). Psychologists link the concept of subjective well-being to the sense of happiness. Freud's pleasure principle, and Maslow's model of the hierarchy of needs represent this approach (Ozan, Mierina, \& Koroleva, 2018). Camarero declares that well-being is measured in terms of outcomes achieved in two broad domains: material living conditions (income and wealth) and quality of life (health status and education) (Camarero, 2019a). Pollock, Ozan, \& Goswami assume that well-being is measured using both objective (GDP and educatio0nal attainment, etc.) and subjective (perceptions and preferences, etc.) measures (Pollock, Ozan, \& Goswami, 2018). Social quality is understood as the extent to which citizens are able to participate in the social and economic life that serve to improve their well-being (Bericat, Camarero, \& Jiménez-Rodrigo, 2019). Meaning in life in association with perceived hope could be considered a protective factor in alleviating the negative effects of distressing events (Krafft \& Walke, 2018b). Schnell views generativity as one of the dimensions of self-transcendence. Studies have found a positive relationship between generativity and psychological well-being (Slezáčková, Cefai, \& Prošek, 2018).

\subsubsection{Hope}

Hope can be viewed either as a changeable phenomenon dependent on the individual's experiences, or as a relatively stable personality trait (Slezáčková, Cefai, \& Prošek, 2018), and is seen as an inner driving force towards a better life (Krafft \& Walker, 2018a). Snyder's hope theory conceptualizes hope as a cognitive-motivational process; the theory has generated amount of relevant researches in affecting students' well-being and academic achievements (Flores-Lucas, Martínez-Sinovas, \& Choubisa, 2018). Snyder has noted the conceptual overlap between his theory of hope and other constructs such as optimism and self-efficacy (Krafft \& Walker, 2018a). Presence of meaning in life has been associated with well-being, including life satisfaction. Increased hope may lead to increased meaning in life, and consequently increase well-being (Guse \& Shaw, 2018). Krafft developed the concept of perceived hope that seeks to assess hope independently from dimensions such as cognitive or social (Slezáčková, Cefai, \& Prošek, 2018).

\subsubsection{Psychological Capital}

The term capital includes not only human capital but psychological and social capital as well. Social capital refers to the ways in which our lives are made more productive by social ties (Sharad \& Misra, 2019). The Putnam conception of social capital was measured by combining social networks with social trust (Camarero, 2019b). Bourdieu defined social capital as "the measurable resource arising from embedded economic relations" (Ní Shé, Burton, \& Danaher, 2018). Prosociality is implicit in trust and cooperation, which are the foundations of social capital (Krishnan, 2019). Societies' cultural activity and creativity are depended on the knowledge and skills people possess, which is its human capital (Herrera-Usagre, 2019). PsyCap has been defined as a positive psychological state of individual development that having positive expectations of success (Flores-Lucas, Martínez-Sinovas, \& Choubisa, 2018). PsyCap incorporates 
self-efficacy and optimism towards goal and hope that no development can take place without investment of PsyCap (Sharad \& Misra, 2019; Moschis, 2019). To provide good academic foundation, higher education institutions ought to indulge in the career development of their students with a much wider perspective.

\subsection{Aims \& Underlying Assumptions}

The author contributes to addressing the following research questions and research hypotheses, which is shown in Table 1. Firstly, what is the role of the demographic structure of the samples (gender, department, age, education, occupation, and income) in enabling social change (optimism and enthusiasm, happy life years, self-efficacy) and hope of life (well-being, basic human needs, life satisfaction)? Secondly, what are the predictability of social change and hope of life? Thirdly, what are the correlation of social change and hope of life? Finally, the paper discusses directions for future researches. These research questions capture the social and psychological debates about the topics of lifelong learning, social exclusion, well-being, hope and psychological capital, and they also assist us to progress our discussions around the hope for a good life. The author attributes the differences to ongoing social change, whereby well-being, hope and education lead to changes in respondents' subjectivities and identities. The specific experiences create a unique framework for viewing their future. The pro-sociality for societal development in the survey "Psychological Perspectives on Perceived Hope" $(\mathrm{n}=221)$ shows how respondents perceive and cope with social change in their lives. It creates a space for action in which the respondents gain life experience and acquire change competence. Demographic trends reveal that the local communities, Taiwan has become increasingly diverse that led to concerns about the implications of social diversity.

Table 1. Research Questions and Hypotheses on Survey "Psychological Perspectives on Perceived Hope"

research questions
1 What is the role of the demographic structure
of the samples (gender, department, age,
education, occupation, and income) in enabling
social change (optimism and enthusiasm, happy
life years, self-efficacy) and hope of life
(well-being, basic human needs, life
satisfaction)?
satisfaction)?

2 What are the predictability of social change and hope of life?

Can the variable "social change"(optimism and enthusiasm, happy life years, self-efficacy) statistically significant predict the variable "hope of life" (well-being, basic human needs, life satisfaction)?

3 What are the correlation of social change and hope of life?

Are there the statistically significant canonical correlation between the variable "social change" (optimism and enthusiasm, happy life years, self-efficacy) and the variable "hope of life" (well-being, basic human needs, life satisfaction)?

\section{research hypotheses}

$\mathrm{H}_{0}$ (null hypothesis) and $\mathrm{H}_{1}$ (alternative hypothesis)

$\mathrm{H}_{0}$ : the difference between the role of the demographic structure of the samples (gender, department, age, education, occupation, and income) in enabling social change (optimism and enthusiasm, happy life years, self-efficacy) and hope of life (well-being, basic human needs, life satisfaction) $=0$.

$\mu_{\text {optimism and enthusiasm }}=\mu_{\text {happy life years }}$
$\mu_{\text {optimism and enthusiasm }}=\mu_{\text {self-efficacy }}$
$\mu_{\text {optimism and enthusiasm }}=\mu_{\text {well-being }}$
$\mu_{\text {optimism and enthusiasm }}=\mu_{\text {basic human needs }}$
$\mu_{\text {optimism and enthusiasm }}=\mu_{\text {life satisfaction }}$
$\mathrm{H}_{1}:$ the difference between the role
samples (gender, department, age, ed
enabling social change (optimism
self-efficacy) and hope of life (we
satisfaction) $\neq 0$.
$\mu_{\text {optimism and enthusiasm }} \neq \mu_{\text {happy life years }}$
$\mu_{\text {optimism and enthusiasm }} \neq \mu_{\text {self-efficacy }}$
$\mu_{\text {optimism and enthusiasm }} \neq \mu_{\text {well-being }}$
$\mu_{\text {optimism and enthusiasm }} \neq \mu_{\text {basic human needs }}$
$\mu_{\text {optimism and enthusiasm }} \neq \mu_{\text {life satisfaction }}$

There are statistically significant prediction between variable "social change" (optimism and enthusiasm, happy life years, self-efficacy) and variable "hope of life" (well-being, basic human needs, life satisfaction).

There are the statistically significant canonical correlation between the variable "social change" (optimism and enthusiasm, happy life years, self-efficacy) and the variable "hope of life" (well-being, basic human needs, life satisfaction). 


\section{Method}

\subsection{Demographic Structure \& Random Sampling}

Most of the survey contain the Likert-type five-point scales dealing with respondents' attitudes toward the general proposition. Data collection was done during school in September-October 2020, over a period of 1-2 months. The random sample is representative of individuals aged 18 years or older who are the students of the National Open University, Taiwan, including a total of 221 respondents of different age ranges, with different educational backgrounds and family status. These students are drawn from 6 department / graduate institute and degree: liberal arts, social science, living sciences, business, public administration, and management and information; 149 (67.4\%) females and $72(32.6 \%)$ males. For data analysis the author only used the fully answered questionnaires of respondents, and removed all those files with obviously incorrect answers. The percentage of removed cases was between $3.0 \%$ and $4.0 \%$. The questionnaire obtained a $90 \%$ response rate. In seeking to give a first impression of the respondents, Table 2 summarises the demographic structure of the samples. For the subscales and statistics about the survey, please see Figure 1 that presents the framework of the empirical study.

\subsection{Questionnaire Design}

The survey consists of a variety of measures that aim to capture the different elements of hope and a set of standardized scales to assess related aspects such as lifelong learning, social exclusion, and psychological capital, etc. The survey questionnaire consists of 51 questions, each of which presents respondents with the statements for approval/rejection, ranking or selection: Firstly, socio-demographic data (gender, department/degree, age, education, occupation and income); Secondly, selection of key change event: the question of whether the changes associated with a life event are evaluated positively or negatively depends on 6 factors: "social change" (optimism and enthusiasm, happy life years, self-efficacy) and "hope of life" (well-being, basic human needs, life satisfaction); Thirdly, there is a multi-choice item for "the reactions in unfamiliar situations"; Fourthly, prioritize assessment of the pro-sociality for societal development (prosocial behaviour, individuals' own life satisfaction). An open response field was added with the request for respondents to indicate the most important changes in their lives.

\subsection{Statistics \& Data Analysis}

IBM SPSS Version 26.0 was utilized to gather descriptive statistics and to determine correlations between factors "social change" (optimism and enthusiasm, happy life years, self-efficacy) and "hope of life" (well-being, basic human needs, life satisfaction). The assessment of the statistical coherence of the framework was undertaken by applying principal component analysis (PCA) to the dataset to identify the main statistical dimensions, then applying item analysis, factor analysis (FA, construct validity) and reliability analysis to analyze the statistical grouping of the scales. The internal consistency of the instruments used was measured with Cronbach's alpha. An independent-samples t-test and one-way ANOVA (Mean, SD, t-test, ANOVA) were employed to determine the differences that "What is the role of the demographic structure of the samples (gender, department/degree, age, education, occupation, and income) in enabling "social change" (optimism and enthusiasm, happy life years, self-efficacy) and "hope of life" (well-being, basic human needs, life satisfaction)"? To test "What are the predictability of social change and hope of life?", the author computed the multiple regression analysis. To test "What are the correlation of social change and hope of life?", the author computed the canonical correlation analysis. To test the multi-choice item for "the reactions in unfamiliar situations", the author computed the cross-table ( $\chi^{2}$, chi-square ). To prioritize assessment of the pro-sociality for societal development (prosocial behaviour, individuals' own life satisfaction), the author computed the frequencies. Table 3 shows the item analysis about scale "social change", Table 4 demonstrates the item analysis about scale "hope of life", Table 5 offers the factor analysis about scale "social change" (secondly), and Table 6 appears the factor analysis about scale "hope of life". The author reports a good reliability Cronbach alpha coefficients of .90 (see Table 7).

Table 2. Demographic Structure of Samples on Survey "Psychological Perspectives on Perceived Hope"

\begin{tabular}{|c|c|c|c|c|c|}
\hline independent variables & $\begin{array}{c}\text { number } \\
\mathrm{N}\end{array}$ & $\begin{array}{c}\text { percent } \\
\%\end{array}$ & independent variables & $\begin{array}{c}\text { number } \\
\mathrm{N}\end{array}$ & $\begin{array}{c}\text { percent } \\
\%\end{array}$ \\
\hline 1gender & 221 & 100.0 & $\begin{array}{l}\text { 4highest level of education that the main } \\
\text { source of the economy at your home }\end{array}$ & 221 & 100.0 \\
\hline (1)male & 72 & 32.6 & $\begin{array}{l}\text { (1)some and completed primary, junior } \\
\text { high school }\end{array}$ & 6 & 2.7 \\
\hline (2)female & 149 & 67.4 & (2)some and completed high school & 76 & 34.4 \\
\hline $\begin{array}{l}\text { 2department / graduate institute } \\
\text { and degree }\end{array}$ & 221 & 100.0 & (3)some and completed college & 116 & 52.5 \\
\hline (1)Department of Liberal Arts & 15 & 6.80 & pleted grac & 23 & 10.4 \\
\hline (2)Department of Social Science & 63 & 28.5 & 5 main occupation that the main source of & 221 & 100.0 \\
\hline
\end{tabular}


(3)Department of Living Sciences

(4)Department of Business

(5)Department of Public Administration

(6)Department of Management and Information

(7)Other

3age

(1)under 25 years old

(2) 25 years old-under 50 years old

(3) 50 years old-under 65 years old (4)over 65 years old the economy at your home

$\begin{array}{lll}64 & 29.0 & \text { (1)military, police and civil service }\end{array}$

$26 \quad 11.8$

(1)military, police and civil service

16.3

$25 \quad 11.3$

(3)housekeeper or unemployment

158

14

$14 \quad 6$.

(4)death or retirement

13

5.9

$14 \quad 6.3$

$221 \quad 100.0$

$16 \quad 7.2$

6average monthly household income

(1) less than 30 thousand ( \$NTD )

100.0

$100 \quad 45.2$

(2) between 30 and less than 60 thousand

(3) between 60 and less than 90 thousand

(4) 90 thousand and over
1 gender

2department / graduate institute and degree

3age

4highest level of education that the main source of the economy at your home

5main occupation that the main source of the economy at your home 6average monthly household income

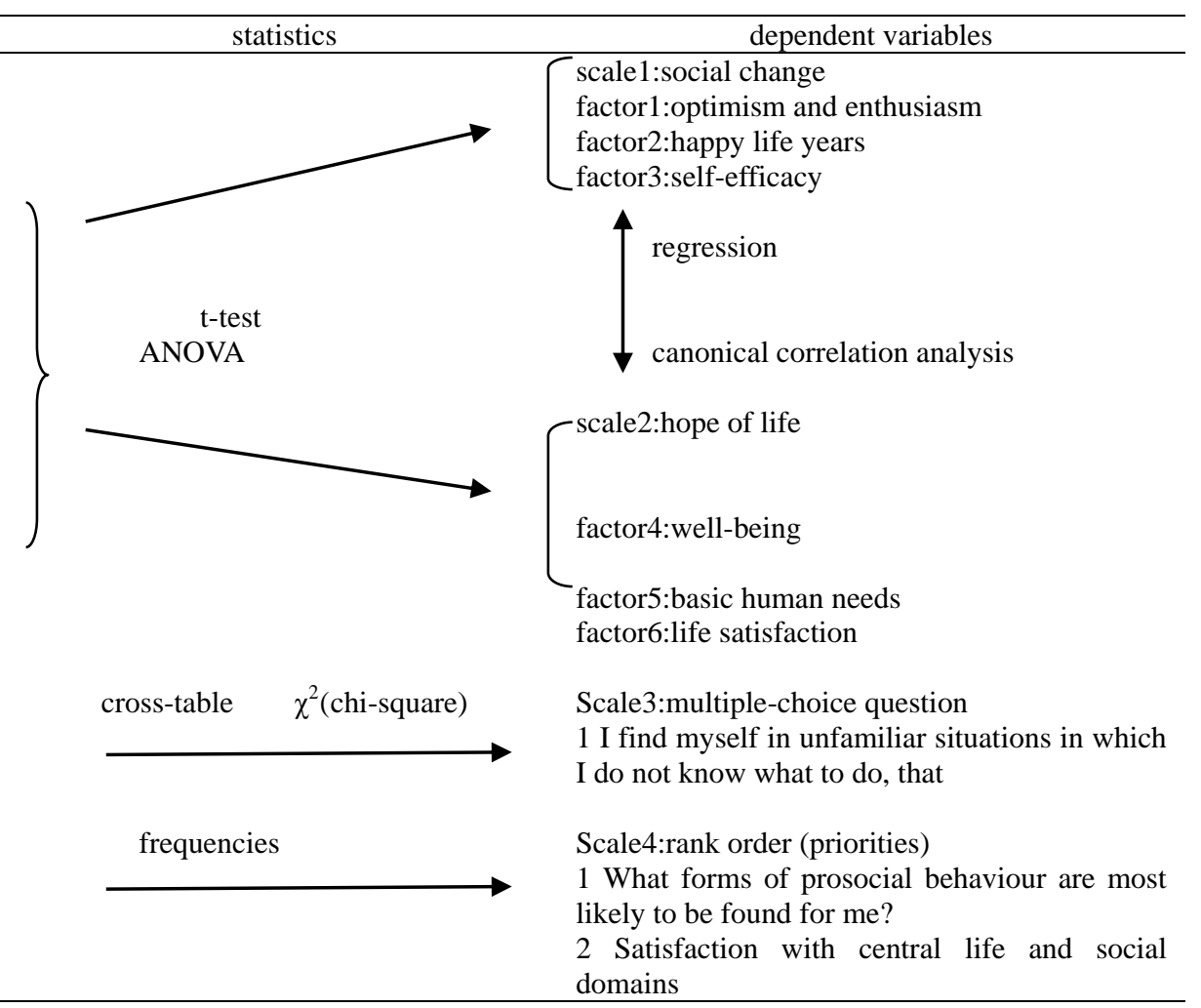
domains

Figure 1. Framework of Empirical Study about Survey "Psychological Perspectives on Perceived Hope"

Table 3. Abstract: Item Analysis about Scale "Social Change"

\begin{tabular}{|c|c|c|c|c|c|c|c|c|}
\hline \multirow[t]{2}{*}{ item } & \multirow{2}{*}{$\begin{array}{c}\begin{array}{c}\text { outlier } \\
\text { studies }\end{array} \\
\text { Critical } \\
\text { Ratio( CR ) }\end{array}$} & \multicolumn{2}{|c|}{$\begin{array}{l}\text { correlation of item and total } \\
\text { score }\end{array}$} & \multicolumn{3}{|c|}{ Homogeneity test } & \multirow{2}{*}{$\begin{array}{l}\text { number } \\
\text { of not up } \\
\text { to } \\
\text { standard }\end{array}$} & \multirow[t]{2}{*}{ remarks } \\
\hline & & $\begin{array}{l}\text { correlation } \\
\text { of item and } \\
\text { total score }\end{array}$ & $\begin{array}{l}\text { correction } \\
\text { about the } \\
\text { correlation of } \\
\text { item and total } \\
\text { score }\end{array}$ & $\begin{array}{c}\text { Cronbach's } \\
\text { Alpha if item } \\
\text { deleted }\end{array}$ & commonality & $\begin{array}{c}\text { factor } \\
\text { loading }\end{array}$ & & \\
\hline b1 & $4.127 * * *$ & $.283 * * *$ & .193 & .893 & .000 & .013 & 5 & retain \\
\hline b2 & $3.516 * *$ & $.291 * * *$ & .225 & .890 & .006 & .078 & 5 & retain \\
\hline b3 & $3.498 * *$ & $.307 * * *$ & .223 & .891 & .003 & .056 & 5 & retain \\
\hline b4 & $4.039 * * *$ & $.342 * * *$ & .255 & .891 & .009 & .097 & 5 & retain \\
\hline b5 & $4.277 * * *$ & $.325 * * *$ & .246 & .890 & .009 & .096 & 5 & retain \\
\hline b6 & $4.606 * * *$ & $.421 * * *$ & .357 & .887 & .038 & .195 & 3 & retain \\
\hline b7 & $4.047 * * *$ & $.349 * * *$ & .271 & .890 & .012 & .111 & 5 & retain \\
\hline b8 & $4.345 * * *$ & $.407 * * *$ & .354 & .887 & .051 & .226 & 3 & retain \\
\hline b9 & $5.531 * * *$ & $.400 * * *$ & .347 & .887 & .059 & .243 & 3 & retain \\
\hline b10 & $3.285^{* *}$ & $.314 * * *$ & .232 & .891 & .001 & .027 & 5 & retain \\
\hline b34 & $9.200 * * *$ & $.572 * * *$ & .510 & .883 & .517 & .719 & 0 & retain \\
\hline
\end{tabular}




\begin{tabular}{|c|c|c|c|c|c|c|c|c|}
\hline b35 & $10.235 * * *$ & $.594 * * *$ & .532 & .883 & .533 & .730 & 0 & retain \\
\hline b36 & $8.690 * * *$ & $.623 * * *$ & .579 & .882 & .516 & .718 & 0 & retain \\
\hline b37 & $9.702 * * *$ & $.644 * * *$ & .602 & .882 & .555 & .745 & 0 & retain \\
\hline b38 & $9.383 * * *$ & $.668 * * *$ & .627 & .881 & .616 & .785 & 0 & retain \\
\hline b39 & $9.412 * * *$ & $.717 * * *$ & .682 & .880 & .654 & .808 & 0 & retain \\
\hline b40 & $10.454 * * *$ & $.719 * * *$ & .681 & .879 & .591 & .769 & 0 & retain \\
\hline b41 & $8.846 * * *$ & $.670 * * *$ & .624 & .881 & .517 & .719 & 0 & retain \\
\hline b42 & $9.257 * * *$ & $.692 * * *$ & .655 & .881 & .581 & .762 & 0 & retain \\
\hline b43 & $8.712 * * *$ & $.661 * * *$ & .621 & .881 & .576 & .759 & 0 & retain \\
\hline b44 & $11.179 * * *$ & $.705 * * *$ & .664 & .880 & .508 & .713 & 0 & retain \\
\hline b45 & $8.401 * * *$ & $.650 * * *$ & .609 & .882 & .580 & .761 & 0 & retain \\
\hline b46 & $10.652 * * *$ & $.700 * * *$ & .660 & .880 & .607 & .779 & 0 & retain \\
\hline b47 & $11.139 * * *$ & $.698 * * *$ & .656 & .880 & .703 & .838 & 0 & retain \\
\hline b48 & $11.238 * * *$ & $.664 * * *$ & .616 & .881 & .513 & .716 & 0 & retain \\
\hline criterion & $\geqq 3.000$ & $\geqq .400$ & $\geqq .400$ & $\leqq .889$ & $\geqq .200$ & $\geqq .450$ & & \\
\hline
\end{tabular}

Table 4. Abstract: Item Analysis about Scale "Hope of Life"

\begin{tabular}{|c|c|c|c|c|c|c|c|c|}
\hline \multirow[t]{2}{*}{ item } & $\begin{array}{l}\text { outlier } \\
\text { studies }\end{array}$ & correlatiol & $\begin{array}{l}\text { item and total } \\
\text { re }\end{array}$ & & mogeneity test & & \multirow{2}{*}{$\begin{array}{c}\text { number } \\
\text { of not up } \\
\text { to } \\
\text { standard }\end{array}$} & \multirow[t]{2}{*}{ remarks } \\
\hline & $\begin{array}{c}\text { Critical } \\
\text { Ratio( CR ) }\end{array}$ & $\begin{array}{l}\text { correlation } \\
\text { of item and } \\
\text { total score }\end{array}$ & $\begin{array}{l}\text { correction } \\
\text { about the } \\
\text { correlation of }\end{array}$ & $\begin{array}{c}\text { Cronbach's } \\
\text { Alpha if item } \\
\text { deleted }\end{array}$ & commonality & $\begin{array}{l}\text { factor } \\
\text { loading }\end{array}$ & & \\
\hline
\end{tabular}

\begin{tabular}{|c|c|c|c|c|c|c|c|c|}
\hline & & & & & & & & \\
\hline b11 & $9.604 * * *$ & $.703 * * *$ & .676 & .965 & .497 & .705 & 0 & retain \\
\hline b12 & $15.475^{* * *}$ & $.714 * * *$ & 684 & .965 & .505 & .711 & 0 & retain \\
\hline b13 & $15.637 * * *$ & $.784 * * *$ & .759 & .964 & .615 & .784 & 0 & retain \\
\hline b14 & $19.180 * * *$ & $.751 * * *$ & .722 & .965 & .559 & .748 & 0 & retain \\
\hline b15 & $13.902 * * *$ & $.771 * * *$ & .746 & .964 & .595 & .771 & 0 & retain \\
\hline b16 & $9.393 * * *$ & $.745 * * *$ & .719 & .965 & .559 & .747 & 0 & retain \\
\hline b17 & $10.549 * * *$ & $.740 * * *$ & .713 & .965 & .550 & .741 & 0 & retain \\
\hline b18 & $8.819 * * *$ & $.699 * * *$ & .671 & .965 & .493 & .702 & 0 & retain \\
\hline b19 & $13.496 * * *$ & $.743 * * *$ & .716 & .965 & .550 & .742 & 0 & retain \\
\hline b20 & $16.183 * * *$ & $.757 * * *$ & .729 & .964 & .569 & .754 & 0 & retain \\
\hline b21 & $14.207 * * *$ & $.758 * * *$ & .731 & .964 & .572 & .756 & 0 & retain \\
\hline b22 & $16.526^{* * *}$ & $.777 * * *$ & .752 & .964 & .602 & .776 & 0 & retain \\
\hline b23 & $13.250 * * *$ & $.796 * * *$ & .773 & .964 & .636 & .797 & 0 & retain \\
\hline b24 & $11.800 * * *$ & $.774 * * *$ & .749 & .964 & .603 & .777 & 0 & retain \\
\hline b25 & $13.892 * * *$ & $.803 * * *$ & .779 & .964 & .649 & .805 & 0 & retain \\
\hline b26 & $12.955 * * *$ & $.702 * * *$ & .674 & .965 & .492 & .701 & 0 & retain \\
\hline b27 & $10.855^{* * *}$ & $.707 * * *$ & .678 & .965 & .502 & .709 & 0 & retain \\
\hline b28 & $16.075^{* * *}$ & $.710 * * *$ & .679 & .965 & .500 & .707 & 0 & retain \\
\hline b29 & $15.548 * * *$ & $.751 * * *$ & .722 & .964 & .560 & .748 & 0 & retain \\
\hline b30 & $14.546^{* * *}$ & $.782 * * *$ & .758 & .964 & .612 & .783 & 0 & retain \\
\hline b31 & $11.998 * * *$ & $.781 * * *$ & .758 & .964 & .614 & .784 & 0 & retain \\
\hline b32 & $20.904 * * *$ & $.844 * * *$ & .827 & .963 & .715 & .846 & 0 & retain \\
\hline b33 & $20.523 * * *$ & $.795 * * *$ & .771 & .964 & .629 & .793 & 0 & retain \\
\hline criterion & $\geqq 3.000$ & $\geqq .400$ & $\geqq .400$ & $\leqq .966$ & $\geqq .200$ & $\geqq .450$ & & \\
\hline 05 & $<.01$ & $<$ & & & & & & \\
\hline
\end{tabular}

Table 5. Abstract: Factor Analysis about Scale "Social Change”(Secondly)

\begin{tabular}{|c|c|c|c|c|}
\hline \multirow{2}{*}{ item } & \multicolumn{3}{|c|}{ factor loading (Varimax Method) } & \multirow{2}{*}{ commonality } \\
\hline & $\begin{array}{c}\text { optimism } \\
\text { and } \\
\text { enthusiasm }\end{array}$ & $\begin{array}{r}\text { happy life } \\
\text { years }\end{array}$ & $\begin{array}{c}\text { self } \\
\text { efficacy }\end{array}$ & \\
\hline b45 I can cope well with most problems on my own. & .850 & .208 & -.038 & .766 \\
\hline b46 As a rule, I am even able to solve arduous and complicated tasks. & .849 & .224 & .026 & .771 \\
\hline b47 I often see several different paths that lead to the goal. & .782 & .411 & -.130 & .797 \\
\hline b42 I will not betray my values for short-term success. & .743 & .311 & .043 & .651 \\
\hline b43 I develop sustainable social contacts and find & .689 & .375 & .018 & .615 \\
\hline
\end{tabular}


relationships.

b44 I feel that my abilities have been confirmed and I would always take the path of change.

b41 If I make an effort, I will also have success

b48 Taiwan creates the conditions for me to reach my full potential.

b36 I have felt the presence of conditions, such as affluence, freedom,

learning, etc.

b38 I am hopeful with regard to my life.

b35 I have felt active and vigorous.

b34 I have felt cheerful and in good spirits.

b37 My daily life has been filled with things that interest me.

b39 I always know where I stand in life

b40 I always succeed in recognizing the major challenges in my life

b5 If I am unlikely to pursue higher education, and my lives continued being defined by necessity and hard work.

b6 Taiwan devotes its heart and soul to keep me and the group together and to create sustainable social relationships.

b1 Schooling is just "Learning to Labour" that lets me "have the knowledge and ability to get jobs and make money".

b4 I devote most of my time to experimenting with different lifestyles and low-paid, temporary work.

Kaiser-Meyer-Olkin (KMO) Measure of Sampling Adequacy (MSA)

Bartltett's Sphericity Test

\begin{tabular}{|c|c|c|c|c|}
\hline & & & & df 171 \\
\hline Eigenvalues & 5.303 & 4.619 & 2.202 & 12.124 \\
\hline Variance Explained \% & 27.909 & 24.309 & 11.590 & 63.808 \\
\hline Cumulative Variance Explained \% & 27.909 & 52.218 & 63.808 & \\
\hline
\end{tabular}

$* \mathrm{p}<.05 \quad * * \mathrm{p}<.01 \quad * * * \mathrm{p}<.001$

Table 6. Abstract: Factor Analysis about Scale "Hope of Life"

\begin{tabular}{|c|c|c|c|c|}
\hline \multirow[t]{2}{*}{ item } & \multicolumn{3}{|c|}{ factor loading (Varimax Method) } & \multirow[t]{2}{*}{ commonality } \\
\hline & well-being & $\begin{array}{l}\text { basic } \\
\text { human } \\
\text { needs }\end{array}$ & $\begin{array}{c}\text { life } \\
\text { satisfaction }\end{array}$ & \\
\hline $\begin{array}{l}\text { b26 I am satisfied with the opportunity in Taiwan, including social status } \\
\text { (class) mobility.(For example, father and child have different occupations } \\
\text { (working class / middle class)) }\end{array}$ & .747 & 287 & .152 & .663 \\
\hline $\begin{array}{l}\text { b25 I am satisfied with the opportunity in Taiwan, including tolerance and } \\
\text { inclusion. }\end{array}$ & .686 & .172 & .526 & .777 \\
\hline b23 I am satisfied with the opportunity in Taiwan, including personal rights. & .660 & .253 & .457 & .708 \\
\hline $\begin{array}{l}\text { b30 I am satisfied with the living opportunity in Taiwan, including } \\
\text { education. }\end{array}$ & .655 & .328 & .358 & .664 \\
\hline b29 I am satisfied with the living opportunity in Taiwan, including housing. & .648 & .479 & .146 & .671 \\
\hline $\begin{array}{l}\text { b32 I am satisfied with the living opportunity in Taiwan, including social } \\
\text { relations. }\end{array}$ & .636 & .495 & .320 & .752 \\
\hline $\begin{array}{l}\text { b24 I am satisfied with the opportunity in Taiwan, including personal } \\
\text { freedom and choice. }\end{array}$ & .634 & .097 & .608 & .781 \\
\hline $\begin{array}{l}\text { b21 I am satisfied with the foundations of wellbeing in Taiwan, including } \\
\text { social insurance. }\end{array}$ & .592 & .569 & .131 & .690 \\
\hline $\begin{array}{l}\text { b27 I am satisfied with the opportunity in Taiwan, including access to } \\
\text { advanced education. }\end{array}$ & .585 & .098 & .539 & .642 \\
\hline b31 I am satisfied with the living opportunity in Taiwan, including health. & .571 & .313 & .467 & .643 \\
\hline $\begin{array}{l}\text { b28 I am satisfied with the living opportunity in Taiwan, including } \\
\text { income/standard of living. }\end{array}$ & .569 & .455 & .184 & .564 \\
\hline $\begin{array}{l}\text { b12 I am satisfied with the basic human needs in Taiwan, including water } \\
\text { and sanitation. }\end{array}$ & .202 & .728 & .311 & .668 \\
\hline $\begin{array}{l}\text { b14 I am satisfied with the basic human needs in Taiwan, including food } \\
\text { safety. }\end{array}$ & .238 & .720 & .349 & .696 \\
\hline $\begin{array}{l}\text { b20 I am satisfied with the foundations of wellbeing in Taiwan, including } \\
\text { national employment. }\end{array}$ & .322 & .710 & .278 & .685 \\
\hline $\begin{array}{l}\text { b19 I am satisfied with the foundations of wellbeing in Taiwan, including } \\
\text { social assistance. }\end{array}$ & .180 & .700 & .421 & .700 \\
\hline b22 I am satisfied with the foundations of wellbeing in Taiwan, inclu & .519 & .648 & .163 & .716 \\
\hline
\end{tabular}


environmental quality.

b33 I am satisfied with the living opportunity in Taiwan, including work.

b15 I am satisfied with the basic human needs in Taiwan, including personal safety.

b17 I am satisfied with the foundations of wellbeing in Taiwan, including access to information and communications.

b18 I am satisfied with the foundations of wellbeing in Taiwan, including health and wellness.

b16 I am satisfied with the foundations of wellbeing in Taiwan, including access to basic knowledge.

b11 I am satisfied with the basic human needs in Taiwan, including nutrition and basic medical care.

b13 I am satisfied with the basic human needs in Taiwan, including shelter.

Kaiser-Meyer-Olkin (KMO) Measure of Sampling Adequacy (MSA)

Bartltett's Sphericity Test

\begin{tabular}{|c|c|c|c|}
\hline .569 & .625 & .165 & .741 \\
\hline .321 & .541 & .484 & .630 \\
\hline 252 & .278 & .778 & .746 \\
\hline 65 & .312 & .768 & .714 \\
\hline 268 & .282 & .767 & .739 \\
\hline 223 & .319 & .702 & .644 \\
\hline 59 & .536 & .580 & .691 \\
\hline & & & $.943 * * *$ \\
\hline & \multicolumn{2}{|c|}{$\chi^{2}$ (Chi-square) } & $\begin{array}{r}4369.258 * * * \\
\text { df } 253\end{array}$ \\
\hline 70 & 5.193 & 5.063 & 15.926 \\
\hline & 22.577 & 22.014 & 69.244 \\
\hline 6 & 47.229 & 69.244 & \\
\hline
\end{tabular}

Eigenvalues

Variance Explained \%

24.652

Cumulative Variance Explained \%

47.229

69.244

$* \mathrm{p}<.05 \quad * * \mathrm{p}<.01 \quad * * * \mathrm{p}<.001$

Table 7. Abstract: Reliability

\begin{tabular}{|c|c|c|}
\hline scale / factor / items & Cronbach's alpha & $\begin{array}{l}\text { Cronbach's Alpha Based on Standardized } \\
\text { Items }\end{array}$ \\
\hline social change (numbers of items 19) & .904 & .915 \\
\hline $\begin{array}{l}\text { optimism and enthusiasm } \\
\text { b41.b42.b43.b44.b45.b46.b47.b48 (numbers of items 8) }\end{array}$ & .916 & .918 \\
\hline $\begin{array}{l}\text { happy life years } \\
\text { b34.b35.b36.b37.b38.b39.b40 (numbers of items 7) }\end{array}$ & .912 & .915 \\
\hline $\begin{array}{l}\text { self-efficacy } \\
\text { b1.b4.b5.b6 (numbers of items 4) }\end{array}$ & .673 & .680 \\
\hline hope of life (numbers of items 23) & .966 & .966 \\
\hline $\begin{array}{l}\text { well-being } \\
\text { b26.b25.b23.b30.b29.b32.b24.b21.b27.b31.b28 (numbers of } \\
\text { items 11) }\end{array}$ & .942 & .942 \\
\hline $\begin{array}{l}\text { basic human needs } \\
\text { b12.b14.b20.b19.b22.b33.b15 (numbers of items 7) }\end{array}$ & .916 & .916 \\
\hline $\begin{array}{l}\text { life satisfaction } \\
\text { b16.b17.b18.b11.b13 (numbers of items 5) }\end{array}$ & .899 & .900 \\
\hline
\end{tabular}

\section{Results}

The objectives of the analysis are to investigate the relation of hope with other related psychological constructs. Firstly, to explore the different aspects of hope as perceived by the Taiwan sample; Secondly, to assess the predictive value of hope in relation to various dimensions for a good life such as optimism and enthusiasm, happy life years, self-efficacy, well-being, basic human needs, and life satisfaction. The results revealed statistically significant positive relationships between the variables. Meaning in life mediated the relationship between the dimensions of hope and related predictors. The author presents a brief summary of the key findings of the empirical evidences that reflect the significance scope of using PsyCap in the educational scenario.

\subsection{What Is the Role of the Demographic Structure of the Samples in Enabling Social Change and Hope of Life?}

The author investigated whether perceived hope and the other variables of interest are affected by the variables: gender, department, age, education, occupation and income. The outcomes of the empirical study are "to explode the $\mathrm{H}_{0}$ (null hypothesis) and accept $\mathrm{H}_{1}$ (alternative hypothesis)".

\subsubsection{Gender}

An independent samples t-test did not reveal any significant gender-related differences in the factors (optimism and enthusiasm, happy life years, self-efficacy, well-being, basic human needs, and life satisfaction) in the sample, which is shown in Table 8, 9, 10, 11, 12, 13. 


\subsubsection{Department / Graduate Institute and Degree}

One-way ANOVA (analysis of variance) did not reveal any significant department-related differences in the factors (optimism and enthusiasm, happy life years, self-efficacy, well-being, basic human needs, and life satisfaction) in the sample, which is shown in Table 8, 9, 10,11, 12, 13.

\subsubsection{Age}

Due to the weak representation of the two age groups (under 25, and over 65) in the samples, these were merged together into "under 50 group" and "50+ group" for the samples. Significant age-related differences were found in the factor: happy life years $(\mathrm{t}=-2.814 ; \mathrm{p}<0.01)$, with"50+ group" $(\mathrm{M}=26.01 ; \mathrm{SD}=4.84)$ exhibiting significantly higher levels of happy life years than "under 50 group" $(\mathrm{M}=24.13$; $\mathrm{SD}=5.06)$, which is shown in Table 9. Significant age-related differences were also found in the factor: well-being $(\mathrm{t}=-2.011 ; \mathrm{p}<0.05)$, with “50+ group" $(\mathrm{M}=37.89$; SD $=8.89$ ) exhibiting significantly higher levels of well-being than "under 50 group" $(\mathrm{M}=35.42$; $\mathrm{SD}=9.27)$, which is shown in Table 11. While no significant differences were found in the factors (optimism and enthusiasm, self-efficacy, basic human needs, and life satisfaction) in the sample, which is shown in Table 8, 10, 12, 13.

\subsubsection{Education}

Due to the weak representation of the two education groups (primary and junior high school, graduate) in the samples, these were merged together into "primary, junior high school, and high school" and "college and graduate" for the samples. Significant education-related differences were found in the factor : optimism and enthusiasm $(t=-4.151 ; \mathrm{p}<$ $0.001)$, with "college and graduate" $(\mathrm{M}=30.34$; $\mathrm{SD}=4.63)$ exhibiting significantly higher levels of optimism and enthusiasm than "primary, junior high school, and high school" $(\mathrm{M}=27.09$; $\mathrm{SD}=6.14)$, which is shown in Table 8. Significant education-related differences were also found in the factor: happy life years $(\mathrm{t}=-3.601 ; \mathrm{p}<0.001)$, with "college and graduate" $(\mathrm{M}=25.99 ; \mathrm{SD}=4.45)$ exhibiting significantly higher levels of happy life years than "primary, junior high school, and high school" $(\mathrm{M}=23.39$; $\mathrm{SD}=5.56)$, which is shown in Table 9. Significant education-related differences were also found in the factor: well-being $(\mathrm{t}=-2.873 ; \mathrm{p}<0.01)$, with "college and graduate" $(\mathrm{M}=38.00$; SD = 8.24) exhibiting significantly higher levels of well-being than "primary, junior high school, and high school" $(\mathrm{M}=$ 34.21; $\mathrm{SD}=10.14$ ), which is shown in Table 11. Significant education-related differences were also found in the factor: life satisfaction $(\mathrm{t}=-2.515 ; \mathrm{p}<0.05)$, with "college and graduate" $(\mathrm{M}=19.09 ; \mathrm{SD}=3.41)$ exhibiting significantly higher levels of life satisfaction than "primary, junior high school, and high school" $(\mathrm{M}=17.50$; $\mathrm{SD}=5.08)$, which is shown in Table 13. While no significant differences were found in the factors (self-efficacy, and basic human needs) in the sample, which is shown in Table 10, 12. It appears to be the field of education that has attracted most attention in relation to psychology and social class. This is perhaps unsurprising given the cultural value placed on education.

\subsubsection{Occupation}

Due to the weak representation of the two age groups (housekeeper or unemployment, death or retirement) in the samples, these were merged together into "military, police and civil service", "agriculture, industry and commerce", and "housekeeper, unemployment, death or retirement" for the samples. One-way ANOVA showed statistically significant occupation-related differences in the factor: life satisfaction $(F=3.399 ; \mathrm{p}<0.05)$ in the sample. The highest level of life satisfaction was among the group "military, police and civil service" $(M=20.11 ; \mathrm{SD}=3.21)$, while the lowest level was found among the group "agriculture, industry and commerce" $(\mathrm{M}=18.13$; $\mathrm{SD}=4.39)$, which is shown in Table 13. However, the post-hoc test confirms the significant differences between occupation groups in the sample. One-way ANOVA carried out on the sample did not show statistically significant occupation-related differences in the factors (optimism and enthusiasm, happy life years, self-efficacy, well-being, and basic human needs) in the Taiwan sample, which is shown in Table 8, 9, 10, 11, 12.

\subsubsection{Income}

Due to the weak representation of the two age groups (60- less than 90 thousand group, and 90+ thousand group) in the samples, these were merged together into "less than 30 thousand", "30- less than 60 thousand", and" 60 thousand and over" for the samples. One-way ANOVA showed statistically significant income-related differences in the factor: self-efficacy $(\mathrm{F}=10.157 ; \mathrm{p}<0.001)$ in the sample. The highest level of self-efficacy was among the group "less than 30 thousand" $(M=15.51 ; S D=2.44)$, and the second high level of self-efficacy was among the group "between 30 and less than 60 thousand" $(M=14.76 ; \mathrm{SD}=3.01)$, while the lowest level was found among the group "60 thousand and over" $(\mathrm{M}=13.26 ; \mathrm{SD}=2.84)$, which is shown in Table 10 . However, the post-hoc test confirms the significant differences between income groups in the sample. One-way ANOVA carried out on the sample did not show statistically significant income-related differences in the factors (optimism and enthusiasm, happy life years, well-being, basic human needs, and life satisfaction) in the sample, which is shown in Table 8, 9, 11, 12, 13. 
Table 8. Abstract: Mean, SD, t-test, ANOVA of Empirical Study about Factor "Optimism and Enthusiasm"

\begin{tabular}{|c|c|c|c|c|c|c|c|c|}
\hline independent variables & $\begin{array}{c}\text { number } \\
\mathrm{N}\end{array}$ & $\begin{array}{c}\text { Mean } \\
\text { M }\end{array}$ & SD & SSB & MSB & $\mathrm{F}$ & $\mathrm{t}$ & $\begin{array}{c}\text { post-hoc } \\
\text { test } \\
\text { Scheffe }\end{array}$ \\
\hline 1gender & & & & & & & .908 & \\
\hline (1)male G1 & 72 & 29.61 & 5.56 & & & & & \\
\hline (2)female $\mathrm{G} 2$ & 149 & 28.90 & 5.41 & & & & & \\
\hline 2department & & & & 7.635 & 3.818 & .127 & & \\
\hline (1)Liberal Arts, Social Science G1 & 78 & 29.32 & 5.55 & & & & & \\
\hline (2)Living Sciences, Business G2 & 90 & 28.91 & 5.38 & & & & & \\
\hline $\begin{array}{l}\text { (3)Public Administration, Management } \\
\text { and Information, Others G3 }\end{array}$ & 53 & 29.23 & 5.55 & & & & & \\
\hline 3age & & & & & & & -1.690 & \\
\hline (1)under 50 years old $\mathrm{G} 1$ & 116 & 28.54 & 5.35 & & & & & \\
\hline (2) 50 years old and over $\mathrm{G} 2$ & 105 & 29.78 & 5.53 & & & & & \\
\hline 4education & & & & & & & $-4.151 * * *$ & $\mathrm{G} 2>\mathrm{G} 1$ \\
\hline $\begin{array}{l}\text { (1)primary, junior high school, and high } \\
\text { schoolG1 }\end{array}$ & 82 & 27.09 & 6.14 & & & & & \\
\hline (2)college and graduate G2 & 139 & 30.34 & 4.63 & & & & & \\
\hline 5occupation & & & & 111.166 & 55.583 & 1.880 & & \\
\hline (1)military, police and civil service G1 & 36 & 30.22 & 5.37 & & & & & \\
\hline (2)agriculture, industry and commerce G2 & 158 & 28.68 & 5.55 & & & & & \\
\hline $\begin{array}{l}\text { (3)housekeeper, unemployment, death or } \\
\text { retirement G3 }\end{array}$ & 27 & 30.30 & 4.81 & & & & & \\
\hline 6income(NTD) & & & & 147.723 & 73.862 & 2.512 & & \\
\hline (1) less than 30 thousand G1 & 43 & 27.51 & 5.92 & & & & & \\
\hline $\begin{array}{l}\text { (2) between } 30 \text { and less than } 60 \text { thousand } \\
\text { G2 }\end{array}$ & 102 & 29.34 & 5.15 & & & & & \\
\hline (3) 60 thousand and over G3 & 76 & 29.76 & 5.49 & & & & & \\
\hline $\begin{array}{l}* \mathrm{p}<.05 \quad * * \mathrm{p}<.01 \\
(\mathrm{MSB})\end{array}$ & & betweer & sum & f squar & (SSB) & betv & groups $\mathrm{m}$ & n square \\
\hline
\end{tabular}

Table 9. Abstract: Mean, SD, t-test, ANOVA of Empirical Study about Factor "Happy Life Years"

\begin{tabular}{|c|c|c|c|c|c|c|c|c|}
\hline independent variables & $\begin{array}{c}\text { number } \\
\mathrm{N}\end{array}$ & $\begin{array}{c}\text { Mean } \\
\mathrm{M}\end{array}$ & SD & SSB & MSB & $\mathrm{F}$ & $\mathrm{t}$ & $\begin{array}{c}\text { post-hoc } \\
\text { test } \\
\text { Scheffe }\end{array}$ \\
\hline 1gender & & & & & & & -.331 & \\
\hline (1)male G1 & 72 & 24.86 & 4.82 & & & & & \\
\hline (2)female G2 & 149 & 25.10 & 5.16 & & & & & \\
\hline 2department & & & & 56.824 & 28.412 & 1.121 & & \\
\hline (1)Liberal Arts, Social Science G1 & 78 & 24.92 & 4.99 & & & & & \\
\hline (2)Living Sciences, Business G2 & 90 & 25.56 & 5.06 & & & & & \\
\hline $\begin{array}{l}\text { (3) Public Administration, Management } \\
\text { and Information, Others G3 }\end{array}$ & 53 & 24.26 & 5.07 & & & & & \\
\hline 3age & & & & & & & $-2.814 * *$ & $\mathrm{G} 2>\mathrm{G} 1$ \\
\hline (1)under 50 years old $\mathrm{G} 1$ & 116 & 24.13 & 5.06 & & & & & \\
\hline (2) 50 years old and over G2 & 105 & 26.01 & 4.84 & & & & & \\
\hline 4education & & & & & & & $-3.601 * * *$ & $\mathrm{G} 2>\mathrm{G} 1$ \\
\hline $\begin{array}{l}\text { (1)primary, junior high school, and high } \\
\text { schoolG1 }\end{array}$ & 82 & 23.39 & 5.56 & & & & & \\
\hline (2)college and graduate G2 & 139 & 25.99 & 4.45 & & & & & \\
\hline 5occupation & & & & 47.078 & 23.539 & .927 & & \\
\hline (1)military, police and civil service G1 & 36 & 25.47 & 4.98 & & & & & \\
\hline (2)agriculture, industry and commerce G2 & 158 & 24.75 & 4.91 & & & & & \\
\hline $\begin{array}{l}\text { (3)housekeeper, unemployment, death or } \\
\text { retirement G3 }\end{array}$ & 27 & 26.04 & 5.85 & & & & & \\
\hline 6income(NTD) & & & & 166.734 & 83.367 & $3.356^{*}$ & & \\
\hline (1) less than 30 thousand G1 & 43 & 23.26 & 5.47 & & & & & \\
\hline (2) between 30 and less than 60 thousand G2 & 102 & 25.43 & 4.79 & & & & & \\
\hline (3) 60 thousand and over G3 & 76 & 25.48 & 4.96 & & & & & \\
\hline
\end{tabular}

$* \mathrm{p}<.05 \quad * * \mathrm{p}<.01 \quad * * * \mathrm{p}<.001 \quad$ between sum of squares (SSB) between groups mean square

(MSB) 
Table 10. Abstract: Mean, SD, t-test, ANOVA of Empirical Study about Factor "Self-Efficacy"

\begin{tabular}{|c|c|c|c|c|c|c|c|c|}
\hline independent variables & $\begin{array}{c}\text { number } \\
\mathrm{N}\end{array}$ & $\begin{array}{c}\text { Mean } \\
\text { M }\end{array}$ & SD & SSB & MSB & $\mathrm{F}$ & $\mathrm{t}$ & $\begin{array}{c}\text { post-hoc } \\
\text { test } \\
\text { Scheffe }\end{array}$ \\
\hline 1gender & & & & & & & .612 & \\
\hline (1)male G1 & 72 & 14.57 & 2.95 & & & & & \\
\hline (2)female G2 & 149 & 14.31 & 2.98 & & & & & \\
\hline 2department & & & & 25.708 & 12.854 & 1.468 & & \\
\hline (1)Liberal Arts, Social Science G1 & 78 & 14.18 & 2.70 & & & & & \\
\hline (2)Living Sciences, Business G2 & 90 & 14.22 & 3.02 & & & & & \\
\hline $\begin{array}{l}\text { (3)Public Administration, Management } \\
\text { and Information, Others G3 }\end{array}$ & 53 & 15.00 & 3.21 & & & & & \\
\hline 3age & & & & & & & .787 & \\
\hline (1)under 50 years old G1 & 116 & 14.54 & 3.02 & & & & & \\
\hline (2)50 years old and over G2 & 105 & 14.23 & 2.91 & & & & & \\
\hline 4education & & & & & & & 1.828 & \\
\hline $\begin{array}{l}\text { (1)primary, junior high school, and high } \\
\text { schoolG1 }\end{array}$ & 82 & 14.87 & 3.05 & & & & & \\
\hline (2)college and graduate G2 & 139 & 14.12 & 2.89 & & & & & \\
\hline 5occupation & & & & 32.293 & 16.146 & 1.850 & & \\
\hline (1)military, police and civil service G1 & 36 & 13.64 & 2.97 & & & & & \\
\hline (2)agriculture, industry and commerce G2 & 158 & 14.46 & 2.96 & & & & & \\
\hline $\begin{array}{l}\text { (3)housekeeper, unemployment, death or } \\
\text { retirement G3 }\end{array}$ & 27 & 15.04 & 2.92 & & & & & \\
\hline 6income(NTD) & & & & 164.917 & 82.459 & $10.157 * * *$ & & $\begin{array}{l}\mathrm{G} 1>\mathrm{G} 3 \\
\mathrm{G} 2>\mathrm{G} 3\end{array}$ \\
\hline (1) less than 30 thousand G1 & 43 & 15.51 & 2.44 & & & & & \\
\hline (2) between 30 and less than 60 thousand G2 & 102 & 14.76 & 3.01 & & & & & \\
\hline (3) 60 thousand and over G3 & 76 & 13.26 & 2.84 & & & & & \\
\hline
\end{tabular}
$* \mathrm{p}<.05 \quad * * \mathrm{p}<.01 \quad * * * \mathrm{p}<.001 \quad$ between sum of squares (SSB) between groups mean square (MSB)

Table 11. Abstract: Mean, SD, t-test, ANOVA of Empirical Study about Factor "Well-Being"

\begin{tabular}{|c|c|c|c|c|c|c|c|c|}
\hline independent variables & $\begin{array}{c}\text { number } \\
\mathrm{N}\end{array}$ & $\begin{array}{c}\text { Mean } \\
\text { M }\end{array}$ & SD & SSB & MSB & $\mathrm{F}$ & $\mathrm{t}$ & $\begin{array}{c}\text { post-hoc } \\
\text { test } \\
\text { Scheffe }\end{array}$ \\
\hline 1gender & & & & & & & -1.077 & \\
\hline (1)male G1 & 72 & 35.64 & 9.79 & & & & & \\
\hline (2)female G2 & 149 & 37.05 & 8.83 & & & & & \\
\hline 2department & & & & 175.331 & 87.665 & 1.046 & & \\
\hline (1)Liberal Arts, Social Science G1 & 78 & 36.53 & 9.18 & & & & & \\
\hline (2)Living Sciences, Business G2 & 90 & 37.48 & 8.68 & & & & & \\
\hline $\begin{array}{l}\text { (3)Public Administration, Management } \\
\text { and Information, Others G3 }\end{array}$ & 53 & 35.19 & 9.89 & & & & & \\
\hline 3age & & & & & & & $-2.011 *$ & $\mathrm{G} 2>\mathrm{G} 1$ \\
\hline (1)under 50 years old G1 & 116 & 35.42 & 9.27 & & & & & \\
\hline (2) 50 years old and over $G 2$ & 105 & 37.89 & 8.89 & & & & & \\
\hline 4education & & & & & & & $-2.873 * *$ & $\mathrm{G} 2>\mathrm{G} 1$ \\
\hline $\begin{array}{l}\text { (1)primary, junior high school, and high } \\
\text { schoolG1 }\end{array}$ & 82 & 34.21 & 10.14 & & & & & \\
\hline (2)college and graduate G2 & 139 & 38.00 & 8.24 & & & & & \\
\hline 5occupation & & & & 269.522 & 134.761 & 1.616 & & \\
\hline (1)military, police and civil service G1 & 36 & 39.00 & 7.69 & & & & & \\
\hline (2)agriculture, industry and commerce G2 & 158 & 35.99 & 9.42 & & & & & \\
\hline $\begin{array}{l}\text { (3)housekeeper, unemployment, death or } \\
\text { retirement G3 }\end{array}$ & 27 & 36.93 & 9.16 & & & & & \\
\hline 6income(NTD) & & & & 287.463 & 143.731 & 1.725 & & \\
\hline (1) less than 30 thousand G1 & 43 & 34.28 & 9.46 & & & & & \\
\hline (2) between 30 and less than 60 thousand G2 & 102 & 37.24 & 9.27 & & & & & \\
\hline (3) 60 thousand and over G3 & 76 & 37.04 & 8.73 & & & & & \\
\hline
\end{tabular}

$* \mathrm{p}<.05 \quad * * \mathrm{p}<.01 \quad * * * \mathrm{p}<.001 \quad$ between sum of squares (SSB) between groups mean square

(MSB) 
Table 12. Abstract: Mean, SD, t-test, ANOVA of Empirical Study about Factor "Basic Human Needs"

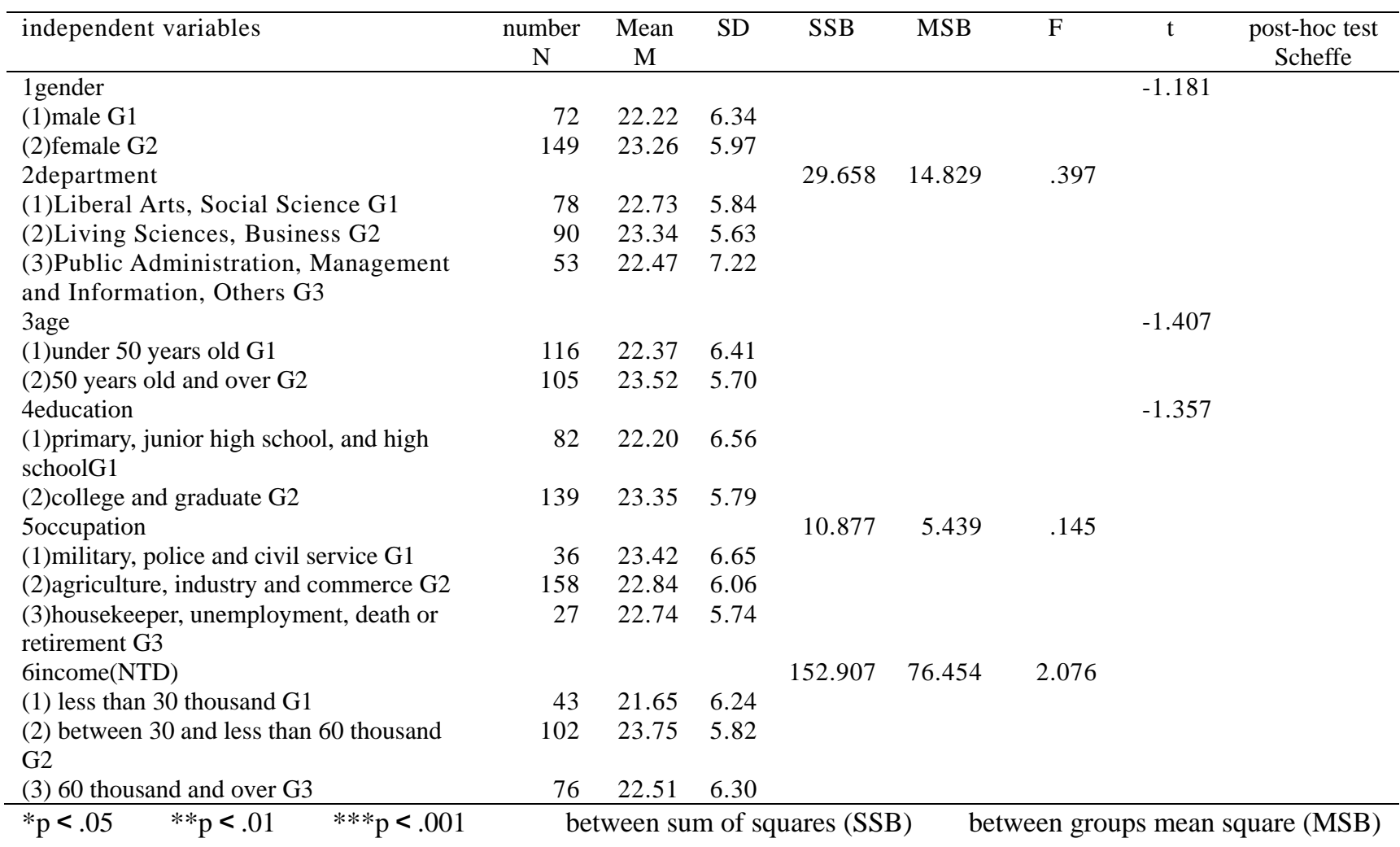

Table 13. Abstract: Mean, SD, t-test, ANOVA of Empirical Study about Factor "Life Satisfaction"

\begin{tabular}{|c|c|c|c|c|c|c|c|c|}
\hline independent variables & $\begin{array}{c}\text { number } \\
\mathrm{N}\end{array}$ & $\begin{array}{c}\text { Mean } \\
M\end{array}$ & SD & SSB & MSB & $\mathrm{F}$ & $\mathrm{t}$ & $\begin{array}{c}\text { post-hoc } \\
\text { test } \\
\text { Scheffe } \\
\end{array}$ \\
\hline 1gender & & & & & & & .246 & \\
\hline (1)male G1 & 72 & 18.60 & 4.47 & & & & & \\
\hline (2)female G2 & 149 & 18.45 & 4.03 & & & & & \\
\hline 2department & & & & 4.694 & 2.347 & .134 & & \\
\hline (1)Liberal Arts, Social Science G1 & 78 & 18.32 & 4.23 & & & & & \\
\hline (2)Living Sciences, Business G2 & 90 & 18.66 & 3.78 & & & & & \\
\hline $\begin{array}{l}\text { (3) Public Administration, Management } \\
\text { and Information, Others G3 }\end{array}$ & 53 & 18.50 & 4.73 & & & & & \\
\hline 3age & & & & & & & -1.417 & \\
\hline (1)under 50 years old G1 & 116 & 18.12 & 4.47 & & & & & \\
\hline (2) 50 years old and over G2 & 105 & 18.91 & 3.78 & & & & & \\
\hline 4education & & & & & & & $-2.515^{*}$ & $\mathrm{G} 2>\mathrm{G} 1$ \\
\hline $\begin{array}{l}\text { (1)primary, junior high school, and high } \\
\text { schoolG1 }\end{array}$ & 82 & 17.50 & 5.08 & & & & & \\
\hline (2)college and graduate G2 & 139 & 19.09 & 3.41 & & & & & \\
\hline 5occupation & & & & 115.484 & 57.742 & $3.399 *$ & & $\mathrm{G} 1>\mathrm{G} 2$ \\
\hline (1)military, police and civil service G1 & 36 & 20.11 & 3.21 & & & & & \\
\hline (2)agriculture, industry and commerce G2 & 158 & 18.13 & 4.39 & & & & & \\
\hline $\begin{array}{l}\text { (3)housekeeper, unemployment, death or } \\
\text { retirement G3 }\end{array}$ & 27 & 18.52 & 3.53 & & & & & \\
\hline 6income(NTD) & & & & 100.891 & 50.445 & 2.958 & & \\
\hline (1) less than 30 thousand G1 & 43 & 17.14 & 4.27 & & & & & \\
\hline (2) between 30 and less than 60 thousand G2 & 102 & 18.73 & 4.30 & & & & & \\
\hline (3) 60 thousand and over G3 & 76 & 18.96 & 3.80 & & & & & \\
\hline$* * * \mathrm{p}<.001$ & betv & een sun & of squ & es (SSB) & bet & $n$ grc & lean sc & e (MSB) \\
\hline
\end{tabular}


Sample multiple regression analysis is reflected in Table 14, 15. As reflected in Table 14, factor "happy life years" had a significant effect on factor "hope of life" ( $\beta=.593 ; \mathrm{p}<0.001$ ); factor "optimism and enthusiasm" also had a significant effect on factor "hope of life" $(\beta=.168 ; \mathrm{p}<0.05)$; factor "self-efficacy" did not have a significant effect on factor "hope of life" $(\beta=.078 ; p>0.05)$. Factors "happy life years" and "optimism and enthusiasm" are both the significant predictors but factor "self-efficacy" does not have the significant explanatory power. By the standardized regression equation, we can understand that the priority of predictors on factor "hope of life" is as follows: "happy life years", "optimism and enthusiasm", and "self-efficacy" which is least valued. Almost $54.3 \%$ of the variance in factor "hope of life" was accounted for by the 3 predictors $\left(\mathrm{R}^{2}=.543\right)$. As expected, there were statistically significant positive correlations among factors "hope of life", "optimism and enthusiasm", and "happy life years".

Similarly, as seen in Table 15, factor "well-being" had a significant effect on factor "social change" $(\beta=.576 ; p<$ 0.001 ); factor "life satisfaction" also had a significant effect on factor "social change" $(\beta=.210 ; p<0.01)$; factor "basic human needs" did not have a significant effect on factor "social change" $(\beta=-.033 ; p>0.05)$. Factors "well-being" and "life satisfaction" are both the significant predictors but factor "basic human needs" does not have the significant explanatory power. By the standardized regression equation, we can understand that the priority of predictors on factor "social change" is as follows: "well-being", "life satisfaction", and "basic human needs" which is least valued. Almost $52.0 \%$ of the variance in factor "social change" was accounted for by the 3 predictors $\left(\mathrm{R}^{2}=.520\right)$. As expected, there were statistically significant positive correlations among factors "social change", "well-being", and "life satisfaction".

Table 14. Multiple Regression Analysis: Factors "Optimism and Enthusiasm", "Happy Life Years" and "Self-Efficacy" Predict "Hope of Life"

\begin{tabular}{|c|c|c|c|c|c|c|c|c|}
\hline & \multirow{2}{*}{$\begin{array}{c}\mathrm{R}^{2} \\
\mathrm{R} \\
\text { Square } \\
/ \\
\mathrm{F}\end{array}$} & \multicolumn{2}{|c|}{$\begin{array}{l}\text { unstandardized } \\
\text { coefficients }\end{array}$} & \multirow{2}{*}{$\begin{array}{c}\text { standardized } \\
\text { coefficients }\end{array}$} & \multirow[b]{2}{*}{$\mathrm{T}$} & \multicolumn{3}{|c|}{ Collinarity diagnosis } \\
\hline & & B & $\begin{array}{l}\text { standardized } \\
\text { error }\end{array}$ & & & Significance & Tolerance & $\begin{array}{c}\text { Variance } \\
\text { Inflation } \\
\text { Factor } \\
\text { VIF }\end{array}$ \\
\hline (constant) & .543 & 1.683 & 5.935 & & .284 & .777 & & \\
\hline $\begin{array}{l}\text { optimism and } \\
\text { enthusiasm }\end{array}$ & $86.064^{* * *}$ & .558 & .240 & .168 & 2.326 & .021 & .402 & 2.488 \\
\hline happy life years & & 2.128 & .258 & .593 & 8.241 & .000 & .407 & 2.458 \\
\hline self-efficacy & & .475 & .283 & .078 & 1.679 & .095 & .977 & 1.024 \\
\hline
\end{tabular}

$* \mathrm{p}<.05 \quad * * \mathrm{p}<.01 \quad * * * \mathrm{p}<.001$

Unstandardized regression equation

$\mathrm{Y}_{\text {hope of life }}=1.683+0.558 \mathrm{x}$ optimism and enthusiasm $+2.128 \mathrm{x}$ happy life years $+0.475 \mathrm{x}$ self-efficacy

Standardized regression equation

$\mathrm{Y}_{\text {hope of life }}=0.168 \mathrm{x}$ optimism and enthusiasm $+0.593 \mathrm{x}$ happy life years $+0.078 \mathrm{x}$ self-efficacy

Table 15. Multiple Regression Analysis: Factors "Well-Being", "Basic Human Needs" and "Life Satisfaction" Predict "Social Change"

\begin{tabular}{|c|c|c|c|c|c|c|c|c|}
\hline & $\begin{array}{l}\mathrm{R}^{2} \\
\mathrm{R}\end{array}$ & $\begin{array}{r}\text { unste } \\
\operatorname{coc}\end{array}$ & $\begin{array}{l}\text { dardized } \\
\text { ficients }\end{array}$ & $\begin{array}{c}\text { standardized } \\
\text { coefficients }\end{array}$ & & & Collinar & diagnosis \\
\hline & $\begin{array}{c}\text { Square } \\
\text { / } \\
\text { F }\end{array}$ & $\mathrm{B}$ & $\begin{array}{l}\text { standardized } \\
\text { error }\end{array}$ & $\begin{array}{c}\text { Beta } \\
\beta\end{array}$ & $\mathrm{T}$ & Significance & $\begin{array}{c}\text { Toleranc } \\
\mathrm{e}\end{array}$ & $\begin{array}{l}\text { Variance } \\
\text { Inflation } \\
\text { Factor , } \\
\text { VIF }\end{array}$ \\
\hline (constant) & .520 & 35.871 & 2.296 & & 15.620 & .000 & & \\
\hline well-being & l & .661 & .103 & .576 & 6.396 & .000 & .273 & 3.669 \\
\hline basic human needs & $78.333^{*}$ & -.057 & .153 & -.033 & -.371 & .711 & .281 & 3.555 \\
\hline life satisfaction & $* *$ & .529 & .195 & .210 & 2.717 & .007 & .371 & 2.698 \\
\hline
\end{tabular}

$* \mathrm{p}<.05 \quad * * \mathrm{p}<.01 \quad * * * \mathrm{p}<.001$

Unstandardized regression equation

$\mathrm{Y}_{\text {social change }}=35.871+0.661 \mathrm{x}$ well-being $+(-0.057) \mathrm{x}$ basic human needs $+0.529 \mathrm{x}$ life satisfaction

Standardized regression equation

$\mathrm{Y}_{\text {social change }}=0.576 \mathrm{x}$ well-being $+(-0.033) \mathrm{x}$ basic human needs $+0.210 \mathrm{x}$ life satisfaction 


\subsection{What Are the Correlation of Social Change and Hope of Life?}

\subsubsection{Canonical Correlation Coefficient}

The 3 factors of the dimension "social change" and the 3 factors of the dimension "hope of life" have 2 canonical correlation coefficient : the first coefficient $\rho 1=.766(p<0.001)$, and the second coefficient $\rho 2=.257(p<0.01)$, which both had a significant effect and was both not zero. For the first canonical variable, the variation that $\chi 1$ and $\eta 1$ can explain each other is $58.7 \%$; for the second canonical variable, the variation that $\chi^{2}$ and $\eta 2$ can explain each other is $6.6 \%$, which is shown in Table 16 and Figure 2.

\subsubsection{Adequacy}

The adequacy of the 2 canonical variables of the dimension "social change" ( $\chi 1$ and $\chi 2)$ can explain the 3 factors ("optimism and enthusiasm", "happy life years", "self-efficacy") are .570 and .243 , and the accumulate variation is $81.30 \%$. Similarly, the adequacy of the 2 canonical variables of the dimension "hope of life" ( $\eta 1$ and $\eta 2$ ) can explain the 3 factors ("well-being", "basic human needs", "life satisfaction") are .771 and .094, and the accumulate variation is $86.50 \%$.

\subsubsection{Redundancy}

By the 2 pairs of canonical variables, the 3 factors ("optimism and enthusiasm", " happy life years", "self-efficacy") of the dimension "social change" $\left(\chi 1\right.$ and $\eta 1 、 \chi^{2}$ and $\left.\eta 2\right)$ can explain the variation of the 3 factors ("well-being", " basic human needs", "life satisfaction") of the dimension "hope of life" are respectively .453 and .006, and the accumulate redundancy is .459. It presents the accumulate redundancy of the dimension "social change" ("optimism and enthusiasm", " happy life years", "self-efficacy") for the dimension "hope of life" ("well-being", "basic human needs", "life satisfaction") is $45.90 \%$. Similarly, by the 2 pairs of canonical variables, the 3 factors ("well-being", " basic human needs", "life satisfaction") of the dimension "hope of life" ( $\eta 1$ and $\chi 1, \eta 2$ and $\left.\chi^{2}\right)$ can explain the variation of the 3 factors ( "optimism and enthusiasm" , "happy life years", "self-efficacy") of the dimension "social change" are .334 and .016, and the accumulate redundancy is .350. It presents the accumulate redundancy of the dimension "hope of life" ("well-being", " basic human needs", "life satisfaction") for the dimension "social change" ("optimism and enthusiasm", " happy life years", "self-efficacy") is $35.0 \%$.

\subsubsection{Canonical Loadings}

By the canonical loadings for the dimension "social change", the higher correlation of the 3 factors ("optimism and enthusiasm" , "happy life years", "self-efficacy") and the canonical variable $\times$ (absolute value $\geqq .500$ ) are 2 factors "optimism and enthusiasm" and " happy life years", and the canonical structure coefficient are both the negative value. The correlation of the 3 factors ("optimism and enthusiasm", " happy life years", "self-efficacy") of the dimension "social change" and the canonical variable X are all the negative value. By the canonical loadings for the dimension "hope of life", the higher correlation of the 3 factors ( "well-being", "basic human needs", "life satisfaction" ) and the canonical variable $\eta$ (absolute value $\geqq .500$ ) are all the 3 factors ("well-being", " basic human needs", and "life satisfaction"), and the canonical structure coefficient are all the negative value. The correlation of the 3 factors ("well-being", "basic human needs", and "life satisfaction") of the dimension "hope of life" and the canonical variable $\mathrm{Y}$ are all the negative value. The 2 dimensions of "social change" and "hope of life" are mutually positive influence.

\subsubsection{Exogenous Variable vs Endogenous Variable}

By the redundancy, the total explained variance of the 3 factors of the dimension "social change" for the 3 factors of the dimension "hope of life" $(=45.90 \%)$, is more than the total explained variance of the 3 factors of the dimension "hope of life" for the 3 factors of the dimension "social change" ( $=35.00 \%)$. The author concludes that the dimension "social change" could be defined as the independent (exogenous) variable, and the dimension "hope of life" could be defined as the dependent (endogenous) variable. 
Table 16. Abstract: Canonical Correlation Analysis (CCA)

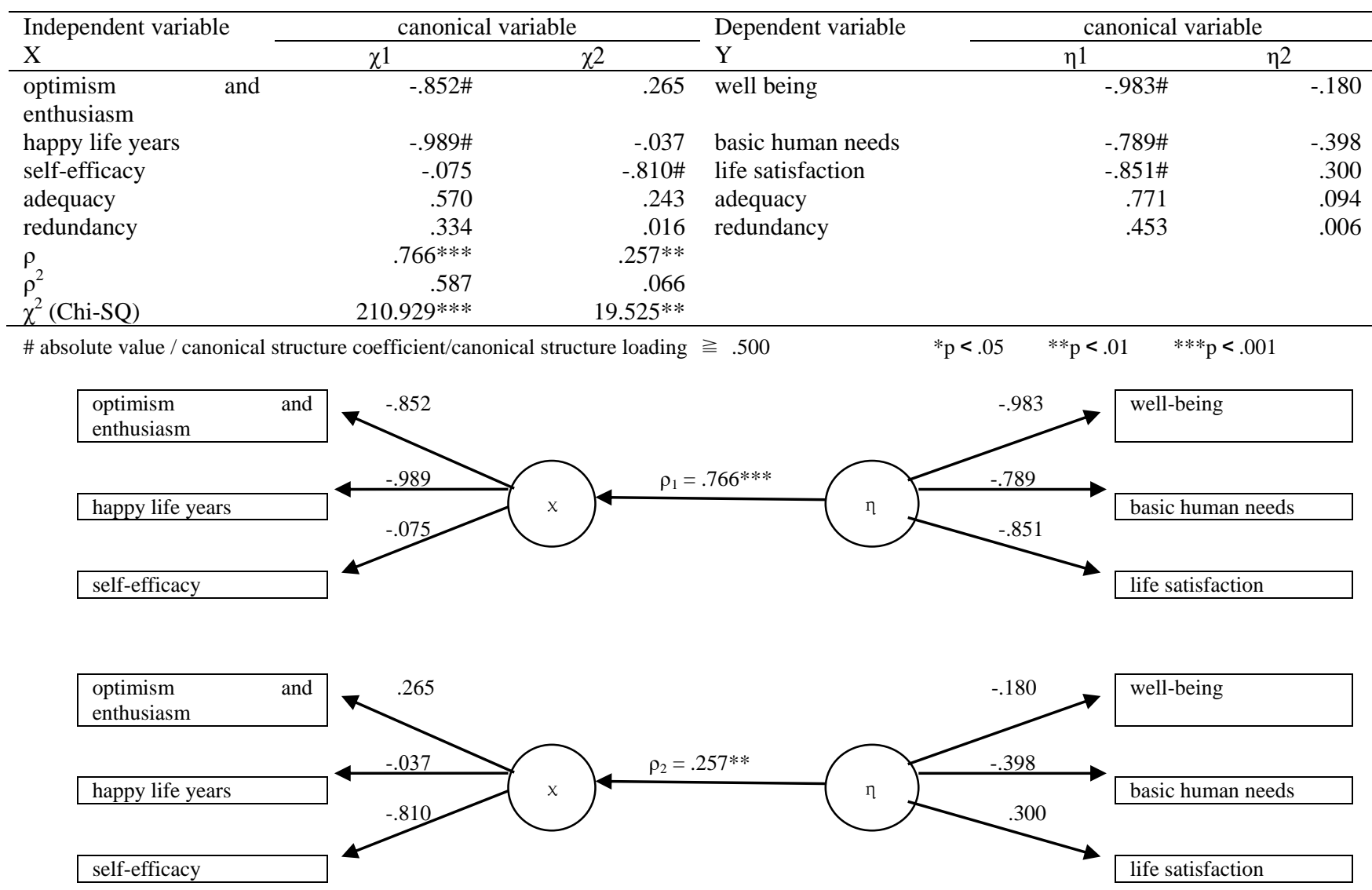

Figure 2. Chart: Canonical Structure Coefficient/Canonical Structure Loading

\subsection{In Unfamiliar Situations in Which I Do not Know What to Do, that...}

65.6 percent of respondents regard the statement "I find myself in unfamiliar situations in which I do not know what to do, that..." as "I am able to overcome difficulties in important situations", 21.7 percent "I sometimes feel like a loser", and 12.7 percent "I feel bored, and I waste time with activities that make little sense", which is shown in Table 17.

Table 17. Abstract: $\chi 2$, The Preferred Choice of Empirical Study about "I find myself in unfamiliar situations in which I do not know what to do, that..."

\begin{tabular}{|c|c|c|c|c|c|c|c|c|c|}
\hline \multirow[t]{2}{*}{$\begin{array}{l}\text { items } \\
\text { independent variables }\end{array}$} & \multicolumn{2}{|c|}{$\begin{array}{l}\text { (1) I feel } \\
\text { bored, and I } \\
\text { waste time } \\
\text { with activities } \\
\text { that make } \\
\text { little sense }\end{array}$} & \multicolumn{2}{|c|}{$\begin{array}{l}\text { (2) I } \\
\text { sometimes feel } \\
\text { like a loser. }\end{array}$} & \multicolumn{2}{|c|}{$\begin{array}{l}\text { (3) I am able } \\
\text { to overcome } \\
\text { difficulties in } \\
\text { important } \\
\text { situations. }\end{array}$} & \multicolumn{2}{|l|}{ total } & \multirow[t]{2}{*}{$\begin{array}{l}\chi^{2} \\
\mathrm{df}\end{array}$} \\
\hline & $\mathrm{N}$ & $\%$ & $\mathrm{~N}$ & $\%$ & $\mathrm{~N}$ & $\%$ & $\mathrm{~N}$ & $\%$ & \\
\hline 1gender & & & & & & & & & 4.698 \\
\hline (1)male G1 & 14 & 19.4 & 13 & 18.1 & 45 & 62.5 & 72 & 32.6 & 2 \\
\hline (2)female G2 & 14 & 9.4 & 35 & 23.5 & 100 & 67.1 & 149 & 67.4 & \\
\hline 2 department & & & & & & & & & 6.102 \\
\hline (1)Liberal Arts, Social Science G1 & 12 & 15.4 & 18 & 23.1 & 48 & 61.5 & 78 & 35.3 & 4 \\
\hline (2)Living Sciences, Business G2 & 7 & 7.8 & 16 & 17.8 & 67 & 74.4 & 90 & 40.7 & \\
\hline $\begin{array}{l}\text { (3)Public Administration, Management } \\
\text { and Information, Others G3 }\end{array}$ & 9 & 17.0 & 14 & 26.4 & 30 & 56.6 & 53 & 24.0 & \\
\hline 3age & & & & & & & & & $7.141 *$ \\
\hline (1)under 50 years old $\mathrm{G} 1$ & 21 & 18.1 & 26 & 22.4 & 69 & 59.5 & 116 & 52.5 & 2 \\
\hline (2) 50 years old and over G2 & 7 & 6.7 & 22 & 21.0 & 76 & 72.4 & 105 & 47.5 & \\
\hline
\end{tabular}


4education

(1)primary, junior high school, and high schoolG1

(2)college and graduate G2

5occupation

(1)military, police and civil service G1

(2)agriculture, industry and commerce G2

(3)housekeeper, unemployment, death or retirement $\mathrm{G} 3$

5 income(NTD)

(1) less than 30 thousand G1

(2) between 30 and less than 60 thousand

G2

\begin{tabular}{lrrrrrrrrr} 
(3) 60 thousand and over G3 & 6 & 7.9 & 20 & 26.3 & 50 & 65.8 & 76 & 34.4 & \\
total & 28 & 12.7 & 48 & 21.7 & 145 & 65.6 & 221 & 100.00 & \\
\hline
\end{tabular}

$* \mathrm{p}<.05 \quad * * \mathrm{p}<.01 \quad * * * \mathrm{p}<.001$

\subsection{Prosocial Behaviour}

For "What forms of prosocial behaviour are most likely to be found for me?", the aspects of first priority are as follows : "help", "social service and positive behavior support", "generosity, donation", "share, support", "sympathy, comfort", "modesty, self-sacrifice", which is shown in Table 18. Again, the aspects of last rank are as follows : "modesty, self-sacrifice"," generosity, donation", "sympathy, comfort", " social service and positive behavior support", "share, support", " help", which is shown in Table 18. The study found a positive relationship between generativity and psychological well-being. Life satisfaction associated with generative behaviour springs from the person's feeling that they made a valuable contribution to the lives of the other people. Generativity was found to be related to prosocial behaviour and engagement in voluntary activities (Krishnan, 2019).

\subsection{Satisfaction with central life and social domains}

The positive responses on individuals' own life satisfaction represent a key result of the change study. For "Please rate the importance of the hopes for myself, including", a clear majority of respondents indicate that they considers national economy (33.9 percent), private life (33.06 percent), food safety (11.8 percent) and contemporary social issues (10.9 percent) important in their life satisfaction, which is shown in Table 18. Somewhat lower values are found for national politics (37.6 percent), private life (24.4 percent), and climate and environment (16.3 percent). The major predictor of perceived hope is the level of expectation about the national economy. The private life, food safety, contemporary social issues, national politics, and climate and environment are of much lower relevance.

Table 18. Abstract: Frequencies, Rank Order (Priorities)

\begin{tabular}{|c|c|c|c|c|}
\hline \multirow[t]{2}{*}{ questions \& items } & \multicolumn{2}{|c|}{ First priority } & \multicolumn{2}{|c|}{ Last rank } \\
\hline & $\mathrm{N}$ & $\%$ & $\mathrm{~N}$ & $\%$ \\
\hline 1 What forms of prosocial behaviour are most likely to be found for me? & \multicolumn{2}{|c|}{$(1)>(6)>(2)>(4)>(5)>(3)$} & \multicolumn{2}{|c|}{$(3)>(2)>(5)>(6)>(4)>(1)$} \\
\hline (1) help & 89 & 40.3 & 12 & 5.4 \\
\hline (2) generosity, donation & 34 & 15.4 & 57 & 25.8 \\
\hline (3) modesty, self-sacrifice & 9 & 4.1 & 62 & 28.1 \\
\hline (4) share, support & 34 & 15.4 & 18 & 8.1 \\
\hline (5) sympathy, comfort & 14 & 6.3 & 44 & 19.9 \\
\hline (6) social service and positive behavior support & 41 & 18.6 & 28 & 12.7 \\
\hline total & 221 & 100.0 & 221 & 100.0 \\
\hline 2 Satisfaction with central life and social domains & \multicolumn{2}{|c|}{$(2)>(1)>(6)>(5)>(3)>(4)$} & \multicolumn{2}{|c|}{$(3)>(1)>(4)>(5)>(2)>(6)$} \\
\hline (1) the private life & 73 & 33.0 & 54 & 24.4 \\
\hline (2) the national economy & 75 & 33.9 & 15 & 6.8 \\
\hline (3) the national politics & 13 & 5.9 & 83 & 37.6 \\
\hline (4) the climate and the environment & 10 & 4.5 & 36 & 16.3 \\
\hline (5) contemporary social issues & 24 & 10.9 & 20 & 9.0 \\
\hline (6) food safety & 26 & 11.8 & 13 & 5.9 \\
\hline total & 221 & 100.0 & 221 & 100.0 \\
\hline
\end{tabular}




\section{Discussion}

It became apparent from the data that there were no discernible patterns to the responses based on the gender and department of the respondents involved. Significant age-related differences of this study were found in the factors: "happy life years" and "well-being", with" $50+$ group" exhibiting significantly higher levels of "happy life years" and "well-being" than "under 50 group". Grouping the respondents based on educational background revealed that people with higher levels of education were typically taking more proactive initiative to manage their "optimism and enthusiasm", "happy life years", "well-being", and "life satisfaction". This is assumed to be because of their increased exposure to different topics and being comfortable with technology. In particular, those lower income earners expressed attitudes favourable to developing their "self-efficacy" more than those higher income earners; the group "military, police and civil service" expressed attitudes favourable to developing their "life satisfaction" more than the group "agriculture, industry and commerce". Although the sample size is small and the categorisation is based on a descriptive analysis, the model enables interpretation a person's behaviour and attitudes with regards to developing their employability and provides a basis for explaining the phenomenon of lifelong employability.

\subsection{Diversity \& Social Development}

The Human Development Index is composed of three dimensions: the health dimension, the education component and the standard of living dimension (Camarero, 2019a). The Global Talent Index combines two variables: the creative class and the educational attainment (Herrera-Usagre, 2019). World Giving Index suggests that pro-sociality underlines human welfare and well-being (Krishnan, 2019). Taiwan is a socially diverse community known for its tolerant and accommodating civilization. But Taiwan found itself embroiled with problems such as poverty and social-economic inequalities. Poverty and deficiency of resources are another challenge; underemployment is challenging economic and social problems. In prosocial exchange, effort-based resources would be seen as higher in cost and therefore would be less likely to be given and accepted, than chance-based resources (Krishnan, 2019). Respondents expressed a preference for helping with their own earned resources (effort-based), than with resources given to them by others (chance-based resources). The Taiwan society has changed in many respects; characteristics of a scarcity culture and 'the image of limited good' seem to exist in Taiwan society. The lower level of generosity among Taiwan subjects was explained in terms of a "limited-good" perception that characterizes scarcity cultures.

\subsection{Social Exclusion}

People try out various lifestyles, and this provides a map of the cultural possibilities and subjectivities (Johansson \& Herz, 2019). The respondents of the survey weigh motives to ensure these factors-optimism and enthusiasm, happy life years, well-being and life satisfaction. If people who fail to gain the hope for a good life, they may develop learned social helplessness which may be sensitive to exclusion that is detrimental to well-being (Fung, Xu, Glazier, Parsons, \& Alden, 2016). Social inclusion is a process which ensures that those at risk of poverty and social exclusion gain the resources necessary to enjoy the well-being (Jiménez-Rodrigo, 2019). The author recommends an array of policies and structural changes that may help to address the classed inequalities, including improvement of living conditions, greater access to labour markets, and better education.

\subsection{Hope for a Good Life}

This analysis allows to highlight the following two findings: Firstly, activities which stand for the "optimism and enthusiasm" and "happy life years" are highly valued by people and also result to have a strong predictive power in relation to a higher level of "hope of life". Secondly, the "self-efficacy" activities, although they are very attractive to many people, did not have the significantly predictive effect on the level of "hope of life". Hope and optimism both are good predictors of psychological well-being and satisfaction with life. According to Erikson hope is the first human virtue and is based on feelings of trust within a social network (Krafft \& Walker, 2018b). Snyder's theory of hope refers to the person's perception in relation to his efficacy to attain personal goals; hope is the process of linking oneself to potential success (Krafft \& Walker, 2018a). These findings suggest that people who report having a meaning in life experience, not only because they experience pleasant thoughts in the present, but also because they hold a positive view of the future.

\subsection{Lifelong Employability through Lifelong Learning}

The population of Taiwan is aging. By 2050, it is predicted that one in four people in Taiwan will be over the age of 65 . People are living longer and, importantly, are healthier for longer. The WHO advocated that when employment, education and social services support older persons' participation in socio-economic activities, they make a productive contribution to society. Learning is important not only to productive ageing, but also to the reinforcement of well-being in later life (Formosa, 2019). The workforce aging and age diversity are the important workforce characteristic to account for requiring talent development policies (Dengler, 2019). Education is a lifelong process and works toward the 
preparation of the individual for a life of meaning and hope (Adjibolosoo, 2018). The economic benefits of supporting lifelong employability are as being "increased competitiveness" and "increased flexibility and ability of employees to deal with change" (Dengler, 2019). The working-class experiences of family relationships within higher education are framed by a discourse of limited social capital and, therefore, fraught with anxiety and fear (Finn, 2015).

\section{Conclusions and Outlook}

Taiwan offers a distinct image of the social composition. This image can be of help in designing social policies and in shaping political discourses sensitive to its societal diversity. This study will be useful for these social, economic, and institutional agents concerned with the education and hope of people, as well as with the quality and cohesion of the society.

\subsection{Challenges and Issues}

\subsubsection{Social Exclusion}

Prosocial values and behaviours would lead to well-being in the form of material and psychological rewards that would facilitate societal development (Krishnan, 2019). More attention needs to be paid to the interaction between endogenous factors (e.g., personality traits) and exogenous variation (e.g., change of the social system, socio-economic events) (Ozan, Mierina, \& Koroleva, 2018). Social exclusion makes people more vulnerable to social influence, and can lead to many physical and psychological problems (Riva, 2016). Hope nurtures the psychological and physical resources to cope with adversity. The hopeful people tend to display a more altruistic and generative behavior by helping others (Krafft \& Walker, 2018a). This survey can help us understand transitions in people's lives. The author hopes the ideas generate enthusiasm for future research on the issue, and also encourages scholars to develop their own theoretical frameworks for how to redress these harmful experiences. Taiwan needs a longitudinal survey of well-being that this can serve as the foundation of causal explanations.

\subsubsection{Education \& PsyCap}

Hope has proved to be an important personal trait and found to be a good predictor of mental health, well-being and academic success. The study reports high levels of well-being and hope among Taiwan Open University students, and adds to knowledge on the construct of perceived hope and PsyCap, opening up further avenues for research on hope and PsyCap. The education research needs to further investigate the PsyCap construct that its positive effects on constructs such as well-being and academic success of our students (Flores-Lucas, Martínez-Sinovas, \& Choubisa, 2018).

\subsubsection{Active Ageing through Lifelong Learning}

Individuals who are able to develop habits in the aspects of lifelong employability and develop openness to experience of work will be the ones who are prepared to navigate a longer life (Dengler, 2019). This paper offers a glimpse of how the massification of HE and a unique insight into the experiences of lifelong learning in Taiwan. It is important to recognise how university-to-work transitions are embedded within experiences of personal life (Finn, 2015). If education does not succeed in expanding the minds of people and enabling them to make pro-life decisions, then it needs to be reformed (Sinha, 2019). But there is the disjoint between the higher education and job openings. A new education system that celebrates inclusive individuality and helps them make creative choices for people livelihood is required (Sinha, 2019). The lifelong learning can arise as an expression of older persons' need to regain power over their own lives (Formosa, 2019).

\subsection{Limitations \& Implications}

\subsubsection{Social Exclusion}

People in Taiwan should have in their minds when they think of Taiwan: a social, economic and culturally heterogeneous reality, and see its societal diversity as its source of wealth (Bericat, 2019). The coping strategies to reduce social exclusion effects are worth being tested in different contexts and with different samples (Eck \& Riva, 2016). Future research should investigate how the change in social networking may change how exclusion is used in social relationships (Wesselmann et al., 2016).

\subsubsection{Education \& PsyCap}

Today, students welcomed the freedom of intellectual exploration, but they also reported high frequencies of stress and exhaustion (Johansson \& Herz, 2019). The construct of PsyCap should be utilized in an educational scenario for effective career development of students. The future research in the field of academic PsyCap is desirable and need to understand the effect of this construct on many academic variables. The educational institutions have to promote the development and implementation of educational or psycho-educational interventions to develop academic PsyCap in students (Flores-Lucas, Martínez-Sinovas, \& Choubisa, 2018). 


\subsubsection{Limitations of the Study \& Avenues for Future Research}

Based on these findings, the further analyses are performed so as to better understand the value of hope for a healthy and happy life (Krafft \& Walker, 2018b). But this study had some limitations. Firstly, this study is a cross-sectional survey, making it impossible to derive causal explanations. In future research, it would be of value to include the survey in longitudinal studies to evaluate reciprocal effects with variables such as psychological capital, education, and hope, etc. Secondly, the self-report character of the questionnaire is another limitation. For example, phenomena such as physical and psychological health should be assessed using medical data to be able to have standardized criteria allowing better comparisons. Thirdly, it utilized a sample derived from a student population, which may limit the generalization of the outcomes to the larger population. It will be useful to implement a similar study among a more representative sample of the Taiwan population. Finally, it may be worthwhile to examine the dynamics of psychological capital, education, and hope, taking into account socio-economic status, marital status, professional status, and culture.

\section{References}

Adjibolosoo, S. (2018). The Human Factor Approach to Managerial and Organizational Efficiency and Effectiveness. Palgrave Macmillan. ISBN 978-3-319-61306-2 ISBN 978-3-319-61307-9 (eBook). https://doi.org/10.1007/978-3-319-61307-9

Backeberg, L., \& Busse, B. (2018). Child and Youth Well-Being on the European Political Agenda. In Gary Pollock, Haridhan Goswami, Anita Stasulane, Jessica Ozan and Gwyther Rees (Eds.), Measuring Youth Well-being. How a Pan-European Longitudinal Survey Can Improve Policy (pp. 15-34). Springer International Publishing AG, part of Springer Nature. ISBN 978-3-319-76062-9 ISBN 978-3-319-76063-6 (eBook). https://doi.org/10.1007/978-3-319-76063-6

Bericat, E. (2019). The Quality of European Societies: An Overview. In Eduardo Bericat and María Luisa Jiménez-Rodrigo (Eds.), The Quality of European Societies. A Compilation of Composite Indicators (pp. 27-50). Springer Nature Switzerland AG. ISBN 978-3-030-05022-1 ISBN 978-3-030-05023-8 (eBook)

Bericat, E., Camarero, M., \& Jiménez-Rodrigo, M. L. (2019). Towards a System of Indices on the Quality of European Societies (SIQES). In Eduardo Bericat and María Luisa Jiménez-Rodrigo (Eds.), The Quality of European Societies. A Compilation of Composite Indicators (pp. 1-26). Springer Nature Switzerland AG. ISBN 978-3-030-05022-1 ISBN 978-3-030-05023-8 (eBook). https://doi.org/10.1007/978-3-030-05023-8_1

Bernstein, M. J. (2016). Research in Social Psychology: Consequences of Short- and Long-Term Social Exclusion. In Paolo Riva and Jennifer Eck (Eds.), Social Exclusion. Psychological Approaches to Understanding and Reducing Its Impact (pp. 51-72). Springer International Publishing Switzerland. ISBN 978-3-319-33031-0 ISBN 978-3-319-33033-4 (eBook). https://doi.org/10.1007/978-3-319-33033-4_3

Berry, J. W. (2019) . Diversity and Equity in Plural Societies: Psychological Perspectives. In Janak Pandey, Rashmi Kumar and Komilla Thapa (Eds.), Psychological Perspectives on Diversity and Social Development (pp. 23-36). Springer Nature Singapore Pte Ltd. ISBN 978-981-13-3340-8 ISBN 978-981-13-3341-5 (eBook). https://doi.org/10.1007/978-981-13-3341-5

Camarero, M. (2019a). Quality of Life. In Eduardo Bericat and María Luisa Jiménez-Rodrigo (Eds.), The Quality of European Societies. A Compilation of Composite Indicators (pp. 51-74). Springer Nature Switzerland AG. ISBN 978-3-030-05022-1 ISBN 978-3-030-05023-8 (eBook)

Camarero, M. (2019b). Social and Political Participation. In Eduardo Bericat and María Luisa Jiménez-Rodrigo (Eds.), The Quality of European Societies. A Compilation of Composite Indicators (pp. 93-110) . Springer Nature Switzerland AG. ISBN 978-3-030-05022-1 ISBN 978-3-030-05023-8 (eBook)

Day, K., Rickett, B., \& Woolhouse, M. (2017). Towards a Critical Social Psychology of Social Class. In Brendan Gough (Eds.), The Palgrave Handbook of Critical Social Psychology (pp. 469-490). This Palgrave Macmillan imprint is published by Springer Nature. ISBN 978-1-137-51017-4 ISBN 978-1-137-51018-1 (eBook). https://doi.org/10.1057/978-1-137-51018-1_23

Dengler, P. (2019). Lifelong Employability. Thriving in an Ageing Society. Springer Fachmedien Wiesbaden GmbH, part of Springer Nature. ISBN 978-3-658-24623-5 ISBN 978-3-658-24624-2 (eBook). https://doi.org/10.1007/978-3-658-24624-2

Druyen, T. (2019). Preface: How to Plan the Future in Times of Exponential Acceleration. Three Scenarios. In Thomas Druyen (Eds.), Radical Change in Everyday Life. Foundations of Psychological Future Management (pp. 1-8). Springer Fachmedien Wiesbaden GmbH, part of Springer Nature. ISBN 978-3-658-25645-6 ISBN 
978-3-658-25646-3 (eBook). https://doi.org/10.1007/978-3-658-25646-3

Duttenhöfer, S. (2019). Experiences of Change - Challenges, Processes and Patterns of Action. In Thomas Druyen (Eds.), Radical Change in Everyday Life. Foundations of Psychological Future Management (pp. 43-78). Springer Fachmedien Wiesbaden $\mathrm{GmbH}$, part of Springer Nature. ISBN 978-3-658-25645-6 ISBN 978-3-658-25646-3 (eBook). https://doi.org/10.1007/978-3-658-25646-3

Eck, J., \& Riva, P. (2016). Bridging the Gap Between Different Psychological Approaches to Understanding and Reducing the Impact of Social Exclusion. In Paolo Riva and Jennifer Eck (Eds.), Social Exclusion. Psychological Approaches to Understanding and Reducing Its Impact (pp. 277-290). Springer International Publishing Switzerland. ISBN 978-3-319-33031-0 ISBN 978-3-319-33033-4 (eBook). https://doi.org/10.1007/978-3-319-33033-4_13

Elenbaas, L., \& Killen, M. (2016). Research in Developmental Psychology: Social Exclusion Among Children and Adolescents. In Paolo Riva and Jennifer Eck (Eds.), Social Exclusion. Psychological Approaches to Understanding and Reducing Its Impact (pp. 89-108). Springer International Publishing Switzerland. ISBN 978-3-319-33031-0 ISBN 978-3-319-33033-4 (eBook). https://doi.org/10.1007/978-3-319-33033-4_5

Finn, K. (2015). Personal Life, Young Women and Higher Education. A Relational Approach to Student and Graduate Experiences. Palgrave Macmillan. ISBN 978-1-349-56859-8 ISBN 978-1-137-31973-9 (eBook). https://doi.org/10.1057/9781137319739

Flores-Lucas, V., Martínez-Sinovas, R., \& Choubisa, R. (2018). Hope and Education: Role of Psychological Capital and Cultural Differences. In Andreas M. Krafft, Pasqualina Perrig-Chiello, and Andreas M. Walker (Eds.), Hope for a Good Life. Results of the Hope-Barometer International Research Program (pp. 199-215). Springer International Publishing AG, part of Springer Naturen. ISBN 978-3-319-78469-4 ISBN 978-3-319-78470-0 (eBook). https://doi.org/10.1007/978-3-319-78470-0

Formosa, M. (2019). Active Ageing Through Lifelong Learning: The University of the Third Age. In Marvin Formosa (Eds.), The University of the Third Age and Active Ageing. European and Asian-Pacific Perspectives (pp. 3-18). Springer Nature Switzerland AG. ISBN 978-3-030-21514-9 ISBN 978-3-030-21515-6 (eBook). https://doi.org/10.1007/978-3-030-21515-6

Fung, K., Xu, C., Glazier, B. L., Parsons, C. A., \& Alden, L. E. (2016). Research in Clinical Psychology: Social Exclusion and Psychological Disorders. In Paolo Riva and Jennifer Eck (Eds.), Social Exclusion. Psychological Approaches to Understanding and Reducing Its Impact (pp. 157-176). Springer International Publishing Switzerland. ISBN 978-3-319-33031-0 ISBN 978-3-319-33033-4 (eBook). https://doi.org/10.1007/978-3-319-33033-4_8

Guse, T., \& Shaw, M. (2018). Hope, Meaning in Life and Well-Being Among a Group of Young Adults. In Andreas M. Krafft, Pasqualina Perrig-Chiello, and Andreas M. Walker (Eds.), Hope for a Good Life. Results of the Hope-Barometer International Research Program (pp. 63-78). Springer International Publishing AG, part of Springer Naturen. ISBN 978-3-319-78469-4 ISBN 978-3-319-78470-0 (eBook). https://doi.org/10.1007/978-3-319-78470-0

Herrera-Usagre, M. (2019). Cultural Practice, Creativity and Innovation. In Eduardo Bericat and María Luisa Jiménez-Rodrigo (Eds.), The Quality of European Societies. A Compilation of Composite Indicators (pp. 111-132). Springer Nature Switzerland AG. ISBN 978-3-030-05022-1 ISBN 978-3-030-05023-8 (eBook).

Jiménez-Rodrigo, M. L. (2019). Social Equality. In Eduardo Bericat and María Luisa Jiménez-Rodrigo (Eds.), The Quality of European Societies. A Compilation of Composite Indicators (pp. 207-230). Springer Nature Switzerland AG. ISBN 978-3-030-05022-1 ISBN 978-3-030-05023-8 (eBook).

Johansson, T., \& Herz, M. (2019). Youth Studies in Transition: Culture, Generation and New Learning Processes. Springer Nature Switzerland AG. ISBN 978-3-030-03088-9 ISBN 978-3-030-03089-6 (eBook). https://doi.org/10.1007/978-3-030-03089-6

Krafft, A. M., \& Walker, A. M. (2018a). Exploring the Concept and Experience of Hope - Theoretical and Methodological Foundations. In Andreas M. Krafft, Pasqualina Perrig-Chiello, and Andreas M. Walker (Eds.), Hope for a Good Life. Results of the Hope-Barometer International Research Program (pp. 3-20). Springer International Publishing AG, part of Springer Naturen. ISBN 978-3-319-78469-4 ISBN 978-3-319-78470-0 (eBook). https://doi.org/10.1007/978-3-319-78470-0

Krafft, A. M., \& Walker, A. M. (2018b). Exploring the Concept and Experience of Hope - Empirical Findings and the Virtuous Circle of Hope. In Andreas M. Krafft, Pasqualina Perrig-Chiello, and Andreas M. Walker (Eds.), Hope for 
a Good Life. Results of the Hope-Barometer International Research Program (pp. 21-62). Springer International Publishing AG, part of Springer Naturen. ISBN 978-3-319-78469-4 ISBN 978-3-319-78470-0 (eBook). https://doi.org/10.1007/978-3-319-78470-0

Krishnan, L. (2019). Prosociality for Societal Development. In Janak Pandey, Rashmi Kumar and Komilla Thapa (Eds.), Psychological Perspectives on Diversity and Social Development (pp. 217-248). Springer Nature Singapore Pte Ltd. ISBN 978-981-13-3340-8 ISBN 978-981-13-3341-5 (eBook). https://doi.org/10.1007/978-981-13-3341-5

Moschis, G. P. (2019). Consumer Behavior over the Life Course. Research Frontiers and New Directions. Springer Nature Switzerland AG. ISBN 978-3-030-05007-8 ISBN 978-3-030-05008-5 (eBook). https://doi.org/10.1007/978-3-030-05008-5

Ní, S. É., Burton, L. J., \& Danaher, P. A. (2018). Enabling States, Capitalising Enterprise and Confronting the Social: Issues and Implications in Researching Contemporary Social Capital and Enterprise. In Éidín Ní Shé, Lorelle J. Burton and Patrick Alan Danaher (Eds.), Social Capital and Enterprise in the Modern State (pp. 3-20). Palgrave Macmillan. ISBN 978-3-319-68114-6 ISBN 978-3-319-68115-3 (eBook). https://doi.org/10.1007/978-3-319-68115-3

O’Reilly, J., \& Banki, S. (2016). Research in Work and Organizational Psychology: Social Exclusion in the Workplace. In Paolo Riva and Jennifer Eck (Eds.), Social Exclusion. Psychological Approaches to Understanding and Reducing Its Impact (pp. 133-156). Springer International Publishing Switzerland. ISBN 978-3-319-33031-0 ISBN 978-3-319-33033-4 (eBook). https://doi.org/10.1007/978-3-319-33033-4_7

Ozan, J., Mierina, I., \& Koroleva, I. (2018). A Comparative Expert Survey on Measuring and Enhancing Children and Young People's Well-Being in Europe. In Gary Pollock, Haridhan Goswami, Anita Stasulane, Jessica Ozan and Gwyther Rees (Eds.), Measuring Youth Well-being. How a Pan-European Longitudinal Survey Can Improve Policy (pp. 35-54). Springer International Publishing AG, part of Springer Nature. ISBN 978-3-319-76062-9 ISBN 978-3-319-76063-6 (eBook). https://doi.org/10.1007/978-3-319-76063-6

Pandey, J. (2019). Psychology and Societal Development: Indian Context. In Janak Pandey, Rashmi Kumar and Komilla Thapa (Eds.), Psychological Perspectives on Diversity and Social Development (pp. 163-180). Springer Nature Singapore Pte Ltd. ISBN 978-981-13-3340-8 ISBN 978-981-13-3341-5 (eBook). https://doi.org/10.1007/978-981-13-3341-5

Pollock, G., Ozan, J., \& Goswami, H. (2018). Notions of Well-Being, the State of Child Well-Being Research and the MYWeB Project. In Gary Pollock, Haridhan Goswami, Anita Stasulane, Jessica Ozan and Gwyther Rees (Eds.), Measuring Youth Well-being. How a Pan-European Longitudinal Survey Can Improve Policy (pp. 1-14). Springer International Publishing AG, part of Springer Nature. ISBN 978-3-319-76062-9 ISBN 978-3-319-76063-6 (eBook). https://doi.org/10.1007/978-3-319-76063-6

Pollock, G., Ozan, J., Goswami, H., \& Fox, C. (2018). With a View Towards the Future: Working Towards an Accelerated European Cohort Survey. In Gary Pollock, Haridhan Goswami, Anita Stasulane, Jessica Ozan and Gwyther Rees (Eds.), Measuring Youth Well-being. How a Pan-European Longitudinal Survey Can Improve Policy (pp. 163-178). Springer International Publishing AG, part of Springer Nature. ISBN 978-3-319-76062-9 ISBN 978-3-319-76063-6 (eBook). https://doi.org/10.1007/978-3-319-76063-6

Riva, P. (2016). Emotion Regulation Following Social Exclusion: Psychological and Behavioral Strategies. In Paolo Riva and Jennifer Eck (Eds.), Social Exclusion. Psychological Approaches to Understanding and Reducing Its Impact (pp. 199-226). Springer International Publishing Switzerland. ISBN 978-3-319-33031-0 ISBN 978-3-319-33033-4 (eBook). https://doi.org/10.1007/978-3-319-33033-4_10

Riva, P., \& Eck, J. (2016). The Many Faces of Social Exclusion. In Paolo Riva and Jennifer Eck (Eds.), Social Exclusion. Psychological Approaches to Understanding and Reducing Its Impact (pp. ix -xv). Springer International Publishing Switzerland. ISBN 978-3-319-33031-0 ISBN 978-3-319-33033-4 (eBook).

Sharad, S., \& Misra, G. (2019). Dynamics of Social Development and Engagement of Authentic Responsible Self. In Janak Pandey, Rashmi Kumar and Komilla Thapa (Eds.), Psychological Perspectives on Diversity and Social Development (pp. 181-200). Springer Nature Singapore Pte Ltd. ISBN 978-981-13-3340-8 ISBN 978-981-13-3341-5 (eBook). https://doi.org/10.1007/978-981-13-3341-5

Sinha, M. (2019). Educated Youth, Employment and Globalized India. In Janak Pandey, Rashmi Kumar and Komilla Thapa (Eds.), Psychological Perspectives on Diversity and Social Development (pp. 249-268). Springer Nature Singapore Pte Ltd. ISBN 978-981-13-3340-8 ISBN 978-981-13-3341-5 (eBook).

https://doi.org/10.1007/978-981-13-3341-5 
Slezáčková, A., Cefai, C., \& Prošek, T. (2018). Psychosocial Correlates and Predictors of Perceived Hope Across Cultures: A Study of Czech and Maltese Contexts. In Andreas M. Krafft, Pasqualina Perrig-Chiello, and Andreas M. Walker (Eds.), Hope for a Good Life. Results of the Hope-Barometer International Research Program (pp. 165-198). Springer International Publishing AG, part of Springer Naturen. ISBN 978-3-319-78469-4 ISBN 978-3-319-78470-0 (eBook). https://doi.org/10.1007/978-3-319-78470-0

Thapa, K. (2019). Introduction: Psychological Perspectives on Diversity and Social Development. In Janak Pandey, Rashmi Kumar and Komilla Thapa (Eds.), Psychological Perspectives on Diversity and Social Development (pp. 1-22). Springer Nature Singapore Pte Ltd. ISBN 978-981-13-3340-8 ISBN 978-981-13-3341-5 (eBook). https://doi.org/10.1007/978-981-13-3341-5

Watts, S. (2017). Relationships: From Social Cognition to Critical Social. In Brendan Gough (Eds.), The Palgrave Handbook of Critical Social Psychology (pp. 365-386). This Palgrave Macmillan imprint is published by Springer Nature. ISBN 978-1-137-51017-4 ISBN 978-1-137-51018-1 (eBook https://doi.org/10.1057/978-1-137-51018-1_18

Wesselmann, E. D., Grzybowski, M. R., Steakley-Freeman, D. M., DeSouza, E. R., Nezlek, J. B., \& Williams, K. D. (2016). Social Exclusion in Everyday Life. In Paolo Riva and Jennifer Eck (Eds.), Social Exclusion. Psychological Approaches to Understanding and Reducing Its Impact (pp. 3-24). Springer International Publishing Switzerland. ISBN 978-3-319-33031-0 ISBN 978-3-319-33033-4 (eBook). https://doi.org/10.1007/978-3-319-33033-4_1

Zittoun, T., \& Gillespie, A. (2018). Imagining the Collective Future: A Sociocultural Perspective. In Constance de Saint-Laurent, Kevin R. Carriere, and Sandra Obradović (Eds.), Imagining Collective Futures. Perspectives from Social, Cultural and Political Psychology (pp. 15-38). The Editor(s) (if applicable) and The Author(s). ISBN 978-3-319-76050-6 ISBN 978-3-319-76051-3 (eBook). https://doi.org/10.1007/978-3-319-76051-3

\section{Copyrights}

Copyright for this article is retained by the author(s), with first publication rights granted to the journal.

This is an open-access article distributed under the terms and conditions of the Creative Commons Attribution license which permits unrestricted use, distribution, and reproduction in any medium, provided the original work is properly cited. 